\title{
Single-Stage Biofilm-Based Total Nitrogen Removal in a Membrane Aerated Biofilm Reactor: Impact of Aeration Mode, HRT and Scouring Intensity
}

\section{Sadaf mehrabi}

Western University

Dwight Houweling

SUEZ Environment: SUEZ

Martha Dagnew ( $\triangle$ mdagnew@uwo.ca )

Western University https://orcid.org/0000-0002-7998-1096

\section{Research Article}

Keywords: Membrane aerated biofilm reactor, aeration mode, ammonia removal, biofilm-based total nitrogen removal, simultaneous nitrification-denitrification, membrane scouring

Posted Date: May 7th, 2021

DOI: https://doi.org/10.21203/rs.3.rs-400202/v1

License: (c) (i) This work is licensed under a Creative Commons Attribution 4.0 International License. Read Full License 


\section{Abstract}

High energy costs, organic carbon availability, and space limitation are some of the barriers faced by wastewater treatment processes. This research investigates the impact of membrane aeration mode, scouring intensity, and loading rate in a single-stage total nitrogen removal process in a membrane aerated biofilm reactor (MABR). Under ammonia loading of $2.7 \mathrm{~g} \mathrm{~N} / \mathrm{m}^{2} . \mathrm{d}$, continuous process aeration led to $1.7 \mathrm{~g} \mathrm{NH}_{4}-\mathrm{N} / \mathrm{m}^{2}$.d and $0.8 \mathrm{~g} \mathrm{TN} / \mathrm{m}^{2}$.d removal, respectively. Conversely, intermittent (5/12 min on/off) aeration resulted in $35 \%$ less ammonia removal but $34 \%$ higher total nitrogen (TN) removal. The MABR under ammonia load of $1.6 \mathrm{~g} \mathrm{~N} / \mathrm{m}^{2}$.d showed an enhanced effluent quality with an average of $2.5 \mathrm{mg} / \mathrm{L}$ effluent ammonia concentration. This finding highlights the nitrification potential of a flow-through MABR as a standalone treatment step without any downstream process. Also, slough-off, a common issue in the biofilm process and was hypothesized to reduce the removal efficiency, showed increased ammonia removal rates by $20 \%$. The microbial analysis indicated the dominant $A O B$ and NOB species as Nitrosomonas spp. and Nitrospira spp, respectively. Moreover, the relative abundance of denitrifying bacteria (40.5\%) were found twice in intermittently-aerated MABR compared to the continuously-aerated one (20.5\%). However, NOB and denitrifying bacteria relative abundances were comparable where continuous air was supplied.

\section{Introduction}

The extent of energy consumption in the biological wastewater treatment industry has become the center of attention in recent years. Population growth and the resulting higher contaminant loading is the motivation to establish energy-efficient approaches. In biological nitrogen removal processes, nitrification and denitrification pathways, the process's energy efficiency can be assessed through aeration in nitrification and carbon demand in denitrification. Total nitrogen removal using a conventional treatment requires substantial biological aeration $\left(4.57 \mathrm{~g} \mathrm{O}_{2} / \mathrm{g} \mathrm{NH}_{4}-\mathrm{N}\right)$ and a carbon demand of $3.71 \mathrm{~g}$ organic carbon/g NO $3-\mathrm{N}$ (Tchobanoglous et al., 2014). Furthermore, processes such as carbon oxidation by aerobic heterotrophs and the use of low-efficiency blowers for oxygen supply influence the energy balance negatively. Alternatively, membrane aerated biofilm reactor (MABR) can be considered to overcome the high energy demand associated with bubble aeration (Houweling et al., 2017b; Martin et al., 2012). MABR technology uses a gas transfer selective membrane to deliver oxygen to a biofilm attached to a membrane surface while other substrates like ammonia and carbon diffuse from the bulk liquid into the biofilm layers (Fig. 1).

Oxygen mass transfer rate (OTR) across the membrane is one of the most critical parameters characterized in MABRs. When the membrane is immersed in clean water with no biofilm grown on, gas flux through the membrane depends on the membrane mass transfer coefficient and the oxygen concentration gradient, influenced by oxygen-water Henry's constant (Cote et al., 1989). However, in a wastewater treatment process where biofilm grows on the membranes' surface, biofilm plays a significant role in determining the oxygen concentration gradient. Biofilm oxygen demand, which is a 
function of biofilm characteristics and operational parameters such as other substrates concentration (nitrogen and carbon), influences the oxygen gradient's extent within the membrane wall in a treatment process (Pellicer-Nàcher et al., 2013; Shanahan and Semmens, 2006). The OTR and OTE are calculated as per equations 1 and 2 (Côté et al., 2015):

$$
\begin{aligned}
& \text { OTR }=\frac{24 \cdot M o}{V m}\left(Q_{P F} \cdot X_{F}-Q_{P E} \cdot X_{E}\right) \\
& \text { OTE }=\frac{J}{24} \frac{V_{m}}{Q_{P F} \cdot M_{O} \cdot X_{F}}
\end{aligned}
$$

Where OTR is in $\mathrm{g} / \mathrm{m}^{2} . \mathrm{d}, \mathrm{M}_{\mathrm{O}}$ is oxygen molecular weight (32 $\left.\mathrm{g} / \mathrm{mol}\right), Q_{P F}$ and $Q_{P E}$ are process gas feed and exhaust specific flow rates $\left(\mathrm{Nm}^{3} / \mathrm{m}^{2} . \mathrm{h}\right), \mathrm{V}_{\mathrm{m}}$ is the standard gas volume at standard temperature and pressure (STP) $\left(0.0224 \mathrm{~m}^{3} / \mathrm{mol}\right)$, and $X_{F}$ and $X_{E}$ are molar fractions of oxygen in feed and exhaust gas.

MABR systems are becoming popular in biological carbon and nitrogen removal processes because of their capability of hosting a higher amount of biomass and, consequently, achieving higher removal rates while saving a considerable amount of oxygen (up to 70\%) compared to conventional systems as well as smaller footprint (Houweling et al., 2017a). Several studies have shown the potential of MABR to address carbon removal, nitrification (municipal and ammonium-rich industrial wastewater) (Da Silva et al., 2018; Downing et al., 2010; Gilmore et al., 2013; Gong et al., 2007; Kunlasubpreedee and Visvanathan, 2020; Pankhania et al., 1999; Premarathna and Visvanathan, 2019; Quan et al., 2018; Semmens, 2005; Stamatopoulou, 2019; Wei et al., 2012), reverse osmosis concentrate, and other chemicals (Lan et al., 2018; Liu et al., 2020; Mei et al., 2019; Potvin et al., 2012; Tian et al., 2019). However, despite the advantages of the simultaneous nitrification-denitrification (SND) process, such as minimizing the cost of extra tanks and recycle streams, research on one-stage biofilm-based SND in MABR is limited. As Table 1 demonstrates, the few MABR studies implementing SND either have obtained low removal efficiencies or have applied longer HRTs (12-28 h) as well as higher C:N (5-18) ratios. However, the C:N ratios that were studied are much higher than the $\mathrm{C}: \mathrm{N}$ ratio $(<3)$ that can be achieved in post-carbon redirection processes, hence further studies at lower $\mathrm{C}: \mathrm{N}$ ratios are required to evaluate the feasibility of using chemically enhanced primary treated (CEPT) wastewater in denitrification without adding any external carbon source. In addition, the longer HRTs considered in previous studies results in larger reactor volume; establishing a robust SND process at relatively lower HRTs (approximately 6-8 times lower than typical HRTs applied in the literature) is of great interest. Another challenge that is supposed to be addressed in this study is comparing MABR performance under intermittent versus continuous aeration mode. Although MABR has been proved as an energy saver in terms of aeration, no investigation has been conducted to examine mainstream SND efficiency in MABR under intermittent aeration condition except the few sidestream (ammonium-rich wastewater) nitritation studies (Ma et al., 2017; Pellicer-Nàcher et al., 2010). 
The counter-diffusional mass transfer pathway occurring within MABR biofilm layers is hypothesized to establish a robust SND system using CEPT wastewater at short HRTs. Overall, in this study, MABR's potential is explored to establish a simultaneous nitrification-denitrification system in the shape of a "single-stage biofilm-based total nitrogen removal system" low-strength municipal wastewater characterized by lower $\mathrm{C}: \mathrm{N}$ ratio. The specific objectives of this study include: 1. Implementing one-stage biofilm-based SND in MABR a) using low-carbon CEPT feed without adding any external carbon source and $b$ ) under quite short HRTs $(2.5 \mathrm{~h}), 2$. Identifying the maximum nitrogen removal efficiency using intermittent aeration and characterizing the trade-off between energy consumption and removal efficiency 
Table 1

Recent mainstream nitrogen removal studies in MABR

\begin{tabular}{|c|c|c|c|c|c|c|}
\hline Process & sC:N & $\begin{array}{l}\text { HRT } \\
\text { (h) }\end{array}$ & $\begin{array}{l}\text { Influent } \\
\mathrm{NH}_{4}-\mathrm{N} \\
(\mathrm{mg} / \mathrm{L})\end{array}$ & $\begin{array}{l}\mathrm{NH}_{4}-\mathrm{N} \text { removal } \\
\text { rate }\left(\mathrm{g} / \mathrm{m}^{2} . \mathrm{d}\right)\end{array}$ & $\begin{array}{l}\text { Biofilm-based TN } \\
\text { removal rate }\left(g / m^{2} . d\right)\end{array}$ & Ref. \\
\hline $\begin{array}{l}\text { COD \& N } \\
\text { removal }\end{array}$ & 15 & 25.5 & 16.4 & 0.5 & 0 & $\begin{array}{l}\text { (Semmens, } \\
\text { 2005) }\end{array}$ \\
\hline $\begin{array}{l}\text { COD \& N } \\
\text { removal* }\end{array}$ & 2.8 & 21 & 25 & 0.27 & 0 & $\begin{array}{l}\text { (Downing } \\
\text { et al., } \\
2010 \text { ) }\end{array}$ \\
\hline \multirow{3}{*}{$\begin{array}{l}\text { COD \& N } \\
\text { removal }\end{array}$} & 3 & \multirow[t]{3}{*}{12} & \multirow[t]{3}{*}{65} & 0.55 & 0.18 & \multirow{3}{*}{$\begin{array}{l}\text { (Sun et al., } \\
\text { 2015) }\end{array}$} \\
\hline & 5 & & & 0.53 & 0.37 & \\
\hline & 7 & & & 0.51 & 0.28 & \\
\hline \multirow[t]{3}{*}{ SND } & \multirow[t]{3}{*}{10} & \multirow[t]{3}{*}{24} & 30 & 0.24 & 0.22 & \multirow{3}{*}{$\begin{array}{l}\text { (Lin et al., } \\
2015)\end{array}$} \\
\hline & & & 70 & 0.46 & 0.44 & \\
\hline & & & 120 & 0.29 & 0.28 & \\
\hline \multirow[t]{4}{*}{ SND } & 10 & \multirow[t]{4}{*}{24} & \multirow[t]{4}{*}{50} & 0.39 & 0.34 & \multirow{4}{*}{$\begin{array}{l}\text { (Lin et al., } \\
\text { 2016) }\end{array}$} \\
\hline & 8 & & & 0.4 & 0.36 & \\
\hline & 5 & & & 0.41 & 0.35 & \\
\hline & 3 & & & 0.38 & 0.23 & \\
\hline$S N D^{a}$ & 5 & 7.6 & 24 & 1.2 & 0 & $\begin{array}{l}\text { (Peeters et } \\
\text { al., 2017) }\end{array}$ \\
\hline SND & 8 & 12 & 25 & 1.02 & 0.45 & $\begin{array}{l}\text { (Li and } \\
\text { Zhang, } \\
\text { 2018) }\end{array}$ \\
\hline SND & 2.7 & 28 & 57 & 0.94 & 0.94 & $\begin{array}{l}\text { (Tian et al., } \\
\text { 2019) }\end{array}$ \\
\hline \multirow{2}{*}{$\begin{array}{l}\text { COD \& N } \\
\text { removal }\end{array}$} & \multirow[t]{2}{*}{5} & 12 & \multirow[t]{2}{*}{50} & 2.22 & 1.85 & \multirow{2}{*}{$\begin{array}{l}\text { (Wu et al., } \\
2019)\end{array}$} \\
\hline & & 20 & & 1.85 & 1.44 & \\
\hline Nitrification & 0 & 2.13 & 60 & $0.7-1.4$ & 0 & $\begin{array}{l}\text { (Castrillo et } \\
\text { al., 2019) }\end{array}$ \\
\hline \multirow{2}{*}{$\begin{array}{l}\text { COD \& N } \\
\text { removal }\end{array}$} & \multirow[t]{2}{*}{18.3} & \multirow[t]{2}{*}{24} & 37 & 1.55 & 0.3 & \multirow{2}{*}{$\begin{array}{l}\text { (Gong et } \\
\text { al., 2020) }\end{array}$} \\
\hline & & & 75 & 3 & 0.9 & \\
\hline
\end{tabular}

${ }^{a}$ MABR-Activated sludge hybrid system 


\section{Materials And Methods}

\subsection{MABR Pilot setup and operation}

The study was conducted using four membrane-aerated biofilm reactor pilots with automatic control capability. Each pilot consisted of a $2 \mathrm{~L}$ membrane tank and a junior Zeelung® membrane module (surface area of $0.14 \mathrm{~m}^{2}$ ). Variable-speed peristaltic pumps (capacity range of $30-450 \mathrm{~mL} / \mathrm{min}$ ) were used to pump feed wastewater into the reactors. Compressed air was used as the process air source, and high-purity (>99.998\%) compressed nitrogen gas was used as the mixing and scouring gas throughout the study. The process air ( $15 \mathrm{~mL} / \mathrm{min})$ was supplied intermittently through the membranes, where it diffused into the biofilm and was used as an electron acceptor during the carbon and ammonia oxidation processes. The intermittent aeration sequence used was $5 \mathrm{~min}$ on and $12 \mathrm{~min}$ off operation. The mixing gas $(170 \mathrm{~mL} / \mathrm{min})$ was directly supplied to the membrane tank continuously to replenish the media with a fresh substrate, whereas the scouring nitrogen gas $(2000 \mathrm{~mL} / \mathrm{min})$ was supplied to the tank intermittently as according to the experimental design. Figure 2 represents a schematic view of the MABR pilot.

Two of the reactors, henceforth referred to as R1 and R2, were operated under the normal scouring condition and HRT of $2.5 \mathrm{~h}$, while one reactor was supplied by intermittent aeration and one by continuous aeration. Normal scouring refers to performing scouring every four hours, with each scouring lasting for one minute. The second set of reactors, R3 and R4, were operated under no scouring condition and HRT of $4 \mathrm{~h}$, one intermittently and one continuously aerated. Aeration, mixing, scouring, and feed-flow control sequences were programmed using Factory Talk® View software (Site Edition, CPR 9 SR 6). Each pilot was equipped with two correlated flowmeters to measure gas flow rates and two pressure gauges to monitor inlet and outlet process air pressures.

\subsection{Wastewater characteristics}

The reactors were seeded with a nitrifying sludge obtained from an activated sludge plant (Vauxhall pollution control plant (PCP), London, Ontario, Canada). Sludge was screened using a $0.2 \mathrm{~mm}$ sieve and then seeded into the MABRs. The reactors were fed with CEPT wastewater from the Vauxhall PCP. $500 \mathrm{~L}$ of feed wastewater was delivered every week, and the feed was stored at room temperature over one week. The average feed ammonia concentration, SCOD concentration, and SCOD:N ratio were $16.9 \pm 4.3$ $\mathrm{mg} \mathrm{NH}_{4}-\mathrm{N} / \mathrm{L}, 33 \pm 11 \mathrm{mg} \mathrm{COD} / \mathrm{L}$, and $2.2 \pm 1.1$, respectively.

\subsection{Sample Analysis}

Samples were collected twice a week from each MABR reactor and the feed wastewater. All samples were analyzed using Hach methods for $\mathrm{NH}_{4}-\mathrm{N}$ (method \#10031), $\mathrm{NO}_{3}-\mathrm{N}$ (method \#10020), $\mathrm{NO}_{2}-\mathrm{N}$ (method \#10019), TCOD, and SCOD (method \#8000). Influent TSS and effluent ML(V)SS were measured following standard methods (Rice et al., 2012). In addition, bulk liquid DO and pH (Orion 087003, Thermo Scientific) were monitored twice per week. The off-gas oxygen fraction was monitored by connecting the oxygen analyzer device $\left(\mathrm{MaxO}_{2}+\mathrm{AE}\right.$, Maxtec) and the AMI oxygen analyzer (model 70R1) directly to the exhaust 
side of the membrane (Fig. 2). At the end of the study, biofilm samples were collected from each reactor to identify the relative abundance of microbial species on the biofilm (Molecular Research, MRDNA, Shallowater, TX, U.S.). Single-factor analysis of variance (ANOVA) was carried out in Excel to discern a significant difference between mean values, and a P-value $<0.05$ is considered significant.

\subsection{Batch Test}

Two batch experiments were conducted to estimate the maximum nitrification and denitrification rates of a well-developed biofilm and compare the maximum total nitrogen removal vs. nitrification rate under intermittent aeration vs. continuous aeration. The batch tests were conducted using CEPT effluent and the MABR pilot that had been operating for over eight months. Before a batch test was initiated, each $M A B R$ was drained entirely and loaded with $2 L$ of feed. For nitrification batch tests, the feed stream was the CEPT wastewater similar to the one used in the long term study, whereas the CEPT wastewater was spiked with $\mathrm{NaNO}_{2}$ and $\mathrm{NaNO}_{3}$ to achieve $15-20 \mathrm{mg} / \mathrm{L}$ of nitrite and nitrate for the nitrite and nitrate denitrification batch tests, respectively. All batch experiments were carried out at $22^{\circ} \mathrm{C}$, and samples were collected every 30 minutes for $\mathrm{NH}_{4}-\mathrm{N}, \mathrm{NO}_{3}-\mathrm{N}, \mathrm{NO}_{2}-\mathrm{N}, \mathrm{sCOD}$, and $\mathrm{DO}$ analysis.

\subsection{Microbial analysis}

At the end of the experiments, biofilm samples grown on the membrane fibers were shipped to Molecular Research DNA LAB (Shallowater, TX, USA) for microbial analysis. The samples were analyzed using the MiSeq sequencing method under bTEFAP. The 16S rRNA gene V4 variable-region PCR primers 515/806 were used in a 30-35 PCR with the HotStarTaq Plus Master Mix Kit (Qiagen, USA) under $94^{\circ} \mathrm{C}$ for 3 minutes, followed by 30 cycles of $94^{\circ} \mathrm{C}$ for $30 \mathrm{~s}, 53^{\circ} \mathrm{C}$ for $40 \mathrm{~s}$, and $72^{\circ} \mathrm{C}$ for 1 minute after final elongation at $72^{\circ} \mathrm{C}$ for 5 minutes. Sequencing was performed on an lon Torrent PGM following the manufacturer's guidelines. Sequence data were processed using a proprietary analysis pipeline (MR DNA, Shallowater, TX, USA).

\section{Results And Discussion}

\subsection{Impact of aeration mode on ammonia and total nitrogen removal: HRT of $2.5 \mathrm{~h}$ with membrane scouring}

Two MABRs were operated for 230 days, under the normally-scoured condition to minimize ammonia diffusion limitation to AOB. Scouring is a typical membrane operation strategy to keep biofilm thickness within an optimum range and minimize mass transfer resistance. Using scouring, ammonia diffusion within the biofilm layers will face less resistance, and consequently, higher ammonia removal efficiency is supposed to occur. In this work, the normal mode of scouring refers to $1 \mathrm{~min}$ long of scouring (2000 $\mathrm{mL} / \mathrm{min}$ ) with four times per day frequency. The ammonia loading rate in previous MABR mainstream wastewater studies ranged between 0.3-7 g/ $\mathrm{m}^{2} . \mathrm{d}$ (Gilmore et al., 2013; Semmens, 2005). In this experiment, the ammonia loading rate was selected as $2.7 \mathrm{~g} / \mathrm{m}^{2} . \mathrm{d}$ resulting in a short HRT of $2.5 \mathrm{~h}$. Although the loading rate of 2.7 is within the typical range for nitrification systems, no studies have been 
found at a shorter HRT of $2.5 \mathrm{~h}$. The shortest HRT used in the previous co-diffusional or counterdiffusional biofilm studies was $7.6 \mathrm{~h}$, while the typical range was 12-28 $\mathrm{h}$ (Table 1). Two different aeration modes, intermittent ( $5 \mathrm{~min}$ On/12 $\mathrm{min}$ Off) and continuous aeration, were applied to R1 and R2.

Figure 3a represents the removal and accumulation of nitrogen compounds in intermittently- (R1) and continuously- (R2) aerated MABRs. Ammonia removal of $62 \%\left(1.7 \mathrm{~g} / \mathrm{m}^{2} . \mathrm{d}\right)$ has been achieved in the continuously-aerated MABR (R2) that is significantly higher than the $40 \%\left(1.1 \mathrm{~g} / \mathrm{m}^{2} . \mathrm{d}\right)$ removal achieved in R1 $(P<0.05)$. Having used an average $\mathrm{C}: \mathrm{N}$ ratio of 2.2 , TN removal efficiencies of $64 \%$ and $47 \%$ were achieved (removal rates of 0.7 and $0.8 \mathrm{~g} / \mathrm{m}^{2} . \mathrm{d}$ ) in R1 and R2, respectively. However, at lower C:N ratios (< 4-5), unstable and low denitrification efficiency has been reported in conventional (co-diffusional) biofilm systems like moving bed biofilm reactor (MBBR), and integrated fixed-film activated sludge (IFAS) (Gu et al., 2018; lannacone et al., 2019; Liao, 2017). It is important to point out that the ammonia and total nitrogen were both removed using the same biofilm. Thus, the biofilm's overall capacity can be estimated by adding the ammonia oxidation and the nitrate or nitrite reduction rate that yields 1.9 and 2.5 $\mathrm{gN} / \mathrm{m}^{2} . \mathrm{d}$ for the intermittently and continuously-aerated MABRs, respectively. Previous studies have looked at biofilm processes for total nitrogen removal from mainstream wastewater using IFAS mode. Nitrification rates of $0.3-1.3 \mathrm{~g} / \mathrm{m}^{2}$. d were reported within the biofilm while the suspended growth bacteria supported the denitrification (Liao, 2017; Onnis-Hayden et al., 2007; Regmi et al., 2011). Regmi et al. (2011) reported a 50\% denitrification rate while using C:N ratio of 7; however, the denitrification occurred in bulk liquid by suspended growth, not by attached growth bacteria (Regmi et al., 2011). A few numbers of investigations using hybrid biofilm and activated sludge systems observed denitrification activity and hypothesized that part of denitrifying activity might belong to the biofilm, but the report lacked further analysis to confirm the hypothesis (Germain et al., 2018; Ito et al., 2019). A study by Peeters et al. (2017) reported relatively higher nitrification rates of 1.2 and $2.6 \mathrm{~g} / \mathrm{m}^{2} . \mathrm{d}$ in a hybrid MABR-activated sludge system where denitrification occurred in the suspended sludge zone rather than the biofilm zone (Peeters et al., 2017).

One of the challenges reported regarding TN removal efficiency is outcompeting denitrifiers by aerobic heterotrophs when $\mathrm{C}: \mathrm{N}$ ratio of 5 and higher is applied (lannacone et al., 2019). Using intermittent aeration mode in MABR, it is hypothesized that developing an environment for the denitrifiers to outcompete the aerobic heterotrophic bacteria for the limited available carbon is a possible counterdiffusional pathway that would limit oxygen availability to the most exterior biofilm layer where the aerobic carbon oxidizing bacteria typically grows. Therefore, the significance of combining counterdiffusional biofilm and supplying intermittent aeration comes to play when dramatically decreased nitrification and denitrification rates can be seen in an MBBR (co-diffusional biofilm) under C:N ratio of 5.6, which caused aerobic heterotrophs overgrowth and consequently out-competing both nitrifiers for oxygen and denitrifiers for carbon (lannacone et al., 2019). Table 2 summarizes the recent co-diffusional biofilm studies conducted to remove total nitrogen from municipal wastewater. 
Table 2

Summary of recent biofilm studies in nitrogen removal

\begin{tabular}{|c|c|c|c|c|c|c|}
\hline Process & Reactor & $\begin{array}{l}\text { HRT } \\
\text { (h) }\end{array}$ & $\begin{array}{l}\text { Inf. NH4 } \\
(\mathrm{mg} / \mathrm{L})\end{array}$ & $\begin{array}{l}\text { Nitrification } \\
\text { rate }\end{array}$ & $\begin{array}{l}\text { Denit. in } \\
\text { biofilm }\end{array}$ & Ref. \\
\hline Nit/denit. & IFAS train & 30 & 40 & $0.35 \mathrm{~g} / \mathrm{m}^{2} . \mathrm{d}$ & None & $\begin{array}{l}\text { (Regmi et al., } \\
\text { 2011) }\end{array}$ \\
\hline Nit/denit & IFAS & N.A. & 35 & $1.12 \mathrm{~g} / \mathrm{m}^{2} . \mathrm{d}$ & None & $\begin{array}{l}\text { (Onnis-Hayden et } \\
\text { al., 2007) }\end{array}$ \\
\hline SND & $\begin{array}{l}\text { Hybrid } \\
\text { RBC }^{a}-A S^{b}\end{array}$ & $\begin{array}{l}8 \\
12\end{array}$ & 38 & $\begin{array}{l}1.63 \mathrm{~g} / \mathrm{m}^{2} . \mathrm{d} \\
1.13 \mathrm{~g} / \mathrm{m}^{2} . \mathrm{d} \\
\text { (in AS) }\end{array}$ & $\begin{array}{l}1.2 \mathrm{~g} / \mathrm{m}^{2} . \mathrm{d} \\
0.86 \\
\mathrm{~g} / \mathrm{m}^{2} . \mathrm{d} \\
\text { (in biofilm) }\end{array}$ & (Ito et al., 2019) \\
\hline Nitrification & IFAS & 10 & 25 & $0.095 \mathrm{~g} / \mathrm{m}^{2} . \mathrm{d}$ & None & (Liao, 2017) \\
\hline Nitrification & $\mathrm{RS}^{\mathrm{c}}$ & 16 & 35 & $0.6 \mathrm{~kg} / \mathrm{m}^{3} / \mathrm{d}$ & None & $\begin{array}{l}\text { (Hewawasam et } \\
\text { al., 2017) }\end{array}$ \\
\hline Nit/denit. & IFAS & 6 & 27 & $0.8 \mathrm{~g} / \mathrm{m}^{2} . \mathrm{d}$ & $\begin{array}{l}0.35 \\
g / m^{2} . d\end{array}$ & $\begin{array}{l}\text { (Germain et al., } \\
\text { 2018) }\end{array}$ \\
\hline SND & MBBR & 48 & 62 & $0.16 \mathrm{~g} / \mathrm{m}^{2} . \mathrm{d}$ & $\begin{array}{l}0.05 \\
\mathrm{~g} / \mathrm{m}^{2} . \mathrm{d}\end{array}$ & $\begin{array}{l}\text { (lannacone et al., } \\
\text { 2019) }\end{array}$ \\
\hline SND & MABR & $\begin{array}{l}2.5 \\
4\end{array}$ & 16.9 & $\begin{array}{l}1.1-1.7 \\
\mathrm{~g} / \mathrm{m}^{2} . \mathrm{d} \\
0.9-1.4 \\
\mathrm{~g} / \mathrm{m}^{2} . \mathrm{d}\end{array}$ & $\begin{array}{l}0.7-0.8 \\
\mathrm{~g} / \mathrm{m}^{2} . \mathrm{d} \\
0.4-0.6 \\
\mathrm{~g} / \mathrm{m}^{2} . \mathrm{d}\end{array}$ & This study \\
\hline
\end{tabular}

a Rotating Biological Contactor

${ }^{b}$ Activated Sludge

${ }^{\mathrm{c}}$ Rotational Sponge

In this study, the average oxygen transfer rate (OTR) and average bulk liquid DO was measured as 5.2 $\mathrm{g} / \mathrm{m}^{2} . \mathrm{d}$ and $0.6 \mathrm{mg} / \mathrm{L}$, respectively. The OTR values were $50 \%$ lower than the one observed in continuous aeration $\left(11.7 \mathrm{~g} / \mathrm{m}^{2} . \mathrm{d}\right)$; however, the bulk liquid DO was slightly lower, where the latter had an average DO of $0.8 \mathrm{mg} / \mathrm{L}$. As a pathway indicator, the ratio of $\mathrm{g} \mathrm{O}_{2}$ consumed $/ \mathrm{g} \mathrm{NH}_{4}-\mathrm{N}_{\text {removed }}$ was calculated as 4.7 and $6.9 \mathrm{~g} / \mathrm{m}^{2}$.d in R1 and R2, respectively. In continuously-aerated MABR, the ratio of 6.9 is relatively higher than the stoichiometric oxygen demand for nitrification ( $4.57 \mathrm{~g} \mathrm{O}_{2}$ consumed $/ \mathrm{g} \mathrm{NH}_{4}$ removed $)$. As a result, although the amount of available carbon was relatively low, the carbon removal pathway included aerobic oxidation and denitrification in continuously-aerated MABR. 
It is also worth noting that, compared to intermittent aeration, a significant proportion $(P<0.05)$ of the oxidized ammonia remained as nitrate in the continuously-aerated MABR $\left(0.4\right.$ and $1 \mathrm{~g} / \mathrm{m}^{2} . \mathrm{d}$ for R1 and $\mathrm{R} 2$, respectively) (Figure $3 \mathrm{a}$ ). Figures $3 \mathrm{~b}$ and $3 \mathrm{c}$ also present ammonia and TN removal efficiency profiles over time. The results demonstrate that $27 \%$ more of the oxidized ammonia was removed as total nitrogen in R1 compared to R2. Remarkably, this correlation between ammonia removal and nitrate production explains the trade-off between intermittent vs. continuous operation: (i) with intermittent aeration: less ammonia removal and having nitrogen gas as the dominant end-product with a saving of $70 \%$ aeration intensity or (ii) with continuous aeration: higher ammonia removal rate with more nitrate as the end-product. This result has further strengthened the conviction that MABR can be used as an adaptable technology depending on the WWTP's treatment goal(s). In WWTPs, which consider ammonia removal as the primary target, and there is no restriction to meet effluent nitrate criteria, continuous aeration will be a wise choice since it can lead to higher ammonia removal efficiency. However, when total nitrogen removal is emphasized in a treatment plant, intermittent aeration can be a suitable strategy to achieve higher total nitrogen removal efficiency.

\subsection{Impact of aeration mode on ammonia and total nitrogen removal: HRT of $\mathbf{4} \mathrm{h}$ associated with no membrane scouring}

The ammonia and total nitrogen removal performance under a lower loading rate of $1.6 \mathrm{~g} / \mathrm{m}^{2} . \mathrm{d}$, resulting in HRT of $4 \mathrm{~h}$, were characterized using a second pair of MABR pilots (R3 and R4). The MABRs were continued from previous research, where they had been running under non-scoured and intermittent aeration mode for $365 d$ (Mehrabi et al., 2020). In this study, both MABRs were continued under nonscoured mode; however, continuous aeration was supplied to R4. Since the ammonia loading rate has been a parameter of interest in characterizing nitrification efficiency, a lower ammonia loading rate was selected in this experiment, comparable to the loading rate used in previous studies that reported higher ammonia removal rates (Lin et al., 2016; Martin et al., 2012). At ammonia loading rate of $1 \mathrm{~g} / \mathrm{m}^{2} . \mathrm{d}$, nitrification efficiency was reported as $98 \%$ in MBBR; however, at higher loadings, decreased nitrification rates were reported (Andreottola et al., 2000). In agreement with the high ammonia removal efficiency at lower ammonia loadings, Lin et al. (2016) reported $0.27 \mathrm{~g} / \mathrm{m}^{2}$.d of ammonia removal rate in MABR when loading was $0.29 \mathrm{~g} / \mathrm{m}^{2}$.d (Lin et al., 2016). On the other hand, Peeters et al. (2017) observed 2.6 and 1.2 $\mathrm{g} / \mathrm{m}^{2}$.d of ammonia removal rates in MABR when ammonia loading was 7 and $3.1 \mathrm{~g} / \mathrm{m}^{2}$.d, respectively (Peeters et al., 2017). In this study, it was hypothesized that using a combination of lower ammonia loading rate and a lower $\mathrm{C}: \mathrm{N}(<3)$ wastewater, the MABR effluent that does not require downstream polishing can be generated.

Figure 4a presents the removal and accumulation rates for different nitrogen compounds in R3 (intermittent aeration) and R4 (continuous aeration) as well as Figs. 4b and 4c which demonstrate ammonia and TN removal efficiency profiles. On day 40 of the 230-day operation period, R4 faced a slough-off phenomenon, and consequently, a significant portion of sludge/biomass was washed out 
from the reactor, and denitrifying activity reached almost zero (Fig. 4c). The collapsed denitrification efficiency due to slough-off proved that the denitrifying population was developed on the biofilm's outer layers. In addition, the fact that the slough-off occurred in the continuously-aerated reactor confirms the overgrowth of heterotrophs and the significance of scouring to control the biofilm thickness. Under the loading of $1.6 \mathrm{~g} / \mathrm{m}^{2} . \mathrm{d}$, continuously-aerated non-scoured MABR (R4) achieved ammonia removal rate of $1.4 \mathrm{~g} / \mathrm{m}^{2} . \mathrm{d}(86 \%)$, which resulted in an average effluent ammonia concentration of $2.5 \mathrm{mg} / \mathrm{L}$ that is aligned with discharge limits. While continuously-aerated non-scoured MABR showed the full capability of removing ammonia with no need for downstream processes, intermittently-aerated MABR (R3) achieved $0.9 \mathrm{~g} / \mathrm{m}^{2} . \mathrm{d}(56 \%)$ ammonia removal rate. In terms of total nitrogen removal, R3 showed a higher TN removal capability of $70 \%$ with $30 \%$ nitrate accumulation, while a much higher nitrate accumulation (87\%) was observed in R4. It should be noted that all the R4 data discussed so far include the whole experiment containing before and after the slough-off phenomenon.

Regarding the performance of R4, ammonia removal efficiency can be divided into two different periods, before and after the slough-off phenomenon. Before slough-off occurred, the ammonia removal efficiency was $75 \%$ in R4, whereas $90 \%$ efficiency was observed after the slough-off. Regarding denitrifying activity, TN removal efficiency dropped from $65-14 \%$, and consequently, residual nitrate increased from $35-85 \%$. These findings indicated that although denitrifying activity was destroyed due to slough-off, a $20 \%$ increase in ammonia removal efficiency was seen, which might be the result of decreased diffusion resistance for ammonia into a thinner biofilm after the slough-off. Slough-off is a common issue in any biofilm process. It is typically accompanied by loss of nitrification activity; however, this study's finding showed that it does not reduce nitrification activity and enhanced ammonia oxidation rate. Increased nitrification rate after the slough-off can confirm the reliability of MABR in terms of ammonia removal.

As discussed earlier, although extensive research has been carried out on SND in conventional biofilm systems, very few numbers of MABR studies explored the possibility of implementing a biofilm-based SND process, particularly for carbon-captured municipal wastewater. Among such MABR studies, some used hybrid systems (which do not support a biofilm-based process), and others have been restricted to apply very long HRTs, higher influent ammonia concentration, and higher C:N ratios (Table 1). For example, Lin et al. (2016) conducted a study that examined the potential of MABR in establishing SND. They reported a $62 \%$ TN removal efficiency at C:N of 3 while HRT was $24 \mathrm{~h}$. However, the same TN removal efficiency was achieved in this study by the HRT of $2.5 \mathrm{~h}$, which translates into a faster process by almost ten times. Hence, we hope that this study's results could eliminate the research gap in using MABR to establish a robust one-stage TN removal system.

Table 3 and Fig. 5 summarized the whole performance of the four MABRs operated under different aeration modes, scouring modes, and HRTs. Comparing ammonia and total nitrogen removal rates and efficiencies in two continuously-aerated MABRs (R2 and R4) but under normal and non-scoured conditions showed a $20 \%$ more ammonia removal in R2 compared to R4. This agrees with the finding obtained in (Mehrabi et al., 2020), where normal scouring led to a higher ammonia removal efficiency than the non-scoured MABRs. The higher ammonia removal corresponding with normal scouring is 
expected to relate with the scouring of the outer heterotrophic carbon oxidizing biofilm layer resulting in a reduced mass transfer resistance for ammonia diffusion through biofilm layers. Another interesting point that came off this experiment is scouring versus non-scouring in TN removal efficiency of the continuously-aerated MABRs. Under continuous aeration condition, the TN removal efficiency remained comparable despite the difference in scouring modes. This observation is quite different from the results reported in the intermittently-aerated reactors (R1 and R3) and also reported by Mehrabi et al. (2020) that indicated a higher TN removal rate of non-scoured MABRs compared to normally-scoured MABRs when intermittent aeration was supplied. That might be justified as when continuous air is introduced to the process, the scouring has no impact on total nitrogen removal efficiency due to the excess air available within the biofilm layers. This unlimited oxygen availability challenges developing an extensive anoxic biofilm layer on the MABR. Typically, the oxygen transfer rate is controlled by the substrate (ammonia and carbon) availability and biomass demand. However, is the observation in this study indicates that the nature of aeration supply mode (intermittent versus continuous) through the membrane also dictates the biochemical environment. Continuous aeration encourages the nitrifying organisms and limits the anoxic zone's availability as a desirable environment for denitrifying activity; however, further biofilm micro-level profiling is required to confirm this observation.

Table 3

Summary of operating conditions and obtained results

\begin{tabular}{|c|c|c|c|c|c|c|c|c|}
\hline \multicolumn{2}{|l|}{$\begin{array}{l}\text { Operating } \\
\text { condition }\end{array}$} & \multicolumn{2}{|c|}{$\mathrm{NH}_{4}-\mathrm{N}\left(\mathrm{g} / \mathrm{m}^{2} \cdot \mathrm{d}\right)$} & \multirow{2}{*}{$\begin{array}{l}\text { OTR } \\
\left(\mathrm{g} / \mathrm{m}^{2} . \mathrm{d}\right)\end{array}$} & \multirow{2}{*}{$\begin{array}{l}\text { TN } \\
\text { removal } \\
\left(\mathrm{g} / \mathrm{m}^{2} . \mathrm{d}\right)\end{array}$} & \multirow{2}{*}{$\begin{array}{l}\mathrm{NO}_{x}-\mathrm{N} \\
\text { residue } \\
\left(\mathrm{g} / \mathrm{m}^{2} \cdot \mathrm{d}\right)\end{array}$} & \multirow{2}{*}{$\begin{array}{l}\text { Effluent } \\
\mathrm{NH}_{4}-\mathrm{N} \\
(\mathrm{mg} / \mathrm{L})\end{array}$} & \multirow{2}{*}{$\begin{array}{l}\text { Effluent } \\
\text { TN } \\
\text { (mg/L) }\end{array}$} \\
\hline $\begin{array}{l}\text { Aeration } \\
\text { mode }\end{array}$ & $\begin{array}{l}\text { HRT } \\
\text { (h) }\end{array}$ & Loading & Removal & & & & & \\
\hline \multirow[t]{2}{*}{ Intermittent } & 2.5 & 2.7 & 1.1 & 5.2 & 0.7 & 0.4 & 10.3 & 13 \\
\hline & 4 & 1.6 & 0.9 & 5.6 & 0.6 & 0.37 & 7.4 & 11.5 \\
\hline \multirow[t]{2}{*}{ Continuous } & 2.5 & 2.7 & 1.7 & 11.7 & 0.8 & 1 & 6.3 & 12.4 \\
\hline & 4 & 1.6 & 1.4 & 10.6 & 0.4 & 1.08 & 2.5 & 14.2 \\
\hline
\end{tabular}

\subsection{Determination of maximum specific substrate removal rate}

Batch experiments were carried out to characterize the performance of the MABRs to remove ammonia and total nitrogen and identify the maximum removal potential of the system. The ammonia oxidation and denitrification rate studies were carried out using CEPT wastewater and spiked CEPT wastewater, respectively (as described in Sect. 2.3). Figures $6 \mathrm{a}$ and $\mathrm{b}$ present the ammonia profile data obtained during the nitrification batch tests. The batch test showed ammonia removal rates of 3.5 and $5.4 \mathrm{~g} / \mathrm{m}^{2} . \mathrm{d}$ in R1 and R2 (intermittent and continuously-aerated reactors at HRT of $2.5 \mathrm{~h}$ ), respectively. As can be seen, the maximum potential of both MABRs is 3.2 times higher than the rates observed in the long-term experiment, representing the substantial nitrification capability of the MABRs if they were run at higher loading rates in a batch mode using a similar HRT of $2.5 \mathrm{~h}$. In non-scoured MABRs (Fig. 6b) where the 
biofilm was developed on a long-term ammonia loading of $1.6 \mathrm{~g} / \mathrm{m}^{2} . \mathrm{d}$, ammonia removal rate obtained in batch tests were 2.3 and $2.9 \mathrm{~g} / \mathrm{m}^{2}$.d in intermittently and continuously-aerated MABRs, respectively. Again, the maximum capability of the non-scoured MABRs is higher than the long-term results by 2-2.5 times; however, it is relatively lower than the maximum capability of the normally-scoured MABRs.

Denitrification rates were also identified in R1 and R2. Both nitrite and nitrate removal rates have been identified as the denitrification capacity of the system. The nitrite removal rate (Fig. 6c) was measured as 5 and $3.5 \mathrm{~g} / \mathrm{m}^{2}$.d under intermittent and continuous aeration. However, the corresponding nitrate removal rates were lower ( 2 and $1.8 \mathrm{~g} / \mathrm{m}^{2}$.d, respectively) (Fig. $6 \mathrm{~d}$ ). The exciting finding is the substantially higher potential (two times) of the system to remove nitrite compared to the nitrate in both reactors. This observation might be due to the concept of biofilm-based SND, which grows both nitrifiers and denitrifiers on the same medium. When denitrifiers grow adjacent to the nitrifiers, they might have the better capability to compete for the NOB for nitrite compared to the systems that denitrifiers mostly grow in suspended activated sludge. As a result, in long-term treatment, the denitrifying population might selectively improve its nitrite reduction capability rather than nitrate. However, due to the high amount of available air in R2, the denitrification rate (including both nitrite and nitrate) is relatively lower than R1, which shows the potential of intermittent aeration in MABR to enhance denitrification activity via nitrite over NOB.

\subsection{Impact of aeration on the microbial community of biofilm}

To further characterize the biological process, the microbial population grown on the surface of membrane fibres were analyzed. The bacterial population are presented in the phylum, class, and specieslevel in Fig. 7. At the phylum level (Fig. 7a), the dominant phylum, which accounted for more than $50 \%$ of the population, is Proteobacteria, including Betaproteobacteria, Gammaproteobacteria, Alphaproteobacteria, Deltaproteobacteria and Epsilonproteobacteria classes, which was reported as the dominant phylum in many WWTPs involved with biological nitrogen and carbon removal processes. Betaproteobacteria and Gammaproteobacteria classes were identified as related bacteria to nitrogen and organic matter removal. Besides, the AOB genera of Nitrosomonas belongs to Betaproteobacteria, which is the dominant AOB genera in both R1 and R2. Bacteroidetes and Chloroflexi, which were identified as two of the most popular phyla in both reactors, were observed as subdominant phyla in several WWTPS (Cydzik-Kwiatkowska and Zielińska, 2016; Gong et al., 2020; Tchobanoglous et al., 2014). The aerobic phylum of Nitrospirae grew in a significantly higher amount under continuous aeration rather than intermittent, which is consistent with the species result reporting Nitrospira $s p$ as the most dominant species in R2 (Fig. 7c). Since unlimited oxygen was supplied to the reaction zone in continuous aeration, it justifies the higher ammonia removal efficiency and higher residual nitrate in R2. Therefore, at the species level, respective AOB and NOB relative abundance (RA) were $10.3 \%$ and $20.7 \%$ under continuous aeration (R2); however, the relative abundance of $A O B$ and NOB were $1.3 \%$ and $1.8 \%$ under intermittent aeration (R1). This finding highlights the fact intermittent aeration significantly limits nitrifiers' growth, which might have simultaneous positive and negative impacts on the process efficiency, as previously 
discussed. The lower NOB relative abundance in intermittently-aerated MABR was in agreement with previous works that reported a decreased nitrite-oxidizing bacterial (NOB) activity and growth rate under intermittent aeration. The authors reported Nitrospira as the dominant NOB species rather than the Nitrobacter that is typical for continuous aeration systems (Mota et al., 2005; Yang and Yang, 2011). Similarly, another study indicated that in the biofilm regions with oxygen scarcity, Nitrospira was found as the dominant species, which has a lower substrate utilization rate than Nitrobacter (Downing and Nerenberg, 2008).

The other striking result of the microbial analysis data is the significantly different relative abundance of nitrifiers vs. denitrifiers in intermittently-aerated MABR vs. the continuously-aerated one. The relative abundance of denitrifying bacteria was measured as $40.5 \%$ in R1, which is two times higher than R2 (20.5\%). It is worth mentioning that $16 \%$ and $6 \%$ of denitrifying bacteria comprised of sulphur-oxidizing bacteria such as Sulfurisoma sediminicola in R1 and R2, respectively, can use nitrate as an electron acceptor and convert it to nitrogen gas. In general, R2 hosted a narrower range of microbial populations, mostly aerobic microorganisms, while R1 grew a vast range of different species, mostly anoxic/anaerobic with denitrifying capability as Sulfurisoma sediminicola, Trichococcus pasteurii, Thiothrix disciformis, and Methyloversatilis. The higher percentage of denitrifiers and higher total nitrogen removal efficiency observed in R1 confirms the hypothesis of a well-developed anoxic region within the intermittentlyaerated biofilm. In other words, denitrifiers could outcompete the NOB population for nitrite due to the favourable anoxic condition; however, NOB and denitrifiers relative abundances were almost equal in R2. Besides, while none of the reactors were seeded with anammox bacteria, it was interesting to find $0.67 \%$ and $0.9 \%$ of anammox bacteria in R1 and R2, respectively. Figure 8 shows the relative abundance of different functional populations in each MABR.

\subsubsection{Impact of biofilm sample extraction method}

For microbial analysis, three biofilm extraction methods from the membrane were utilized. The methods include Qiagen Powersoil DNA extraction kit, Ultrasonic bath, and Vortex Mixer were examined. In both ultrasonic bath (30 min, $70 \mathrm{kHz}$ ) and vortex mixer (3 min, $2500 \mathrm{rpm})$, distilled water was used as the solvent. According to the analysis results, significant differences were reported in the relative abundance of microbial populations using three different extraction methods. The relative abundance of $A O B, N O B$, and denitrifying bacteria for ultrasonic bath and vortex mixer methods was detected as approximately $50 \%$ lower than using the Qiagen Powersoil DNA extraction kit RA of denitrifying bacteria using vortex mixer in R1 (Fig. 9). Regardless of the negative or positive error percentage, both ultrasonic bath and vortex mixers were found highly unreliable methods to extract the biofilm sample from the media comparing to the Qiagen Powersoil DNA extraction kit.

\section{Conclusion}

In this study, a single-stage biofilm-based total nitrogen removal was established to treat CEPT wastewater using MABR at short HRT of up to $2.5 \mathrm{~h}$. The obtained results underlined the importance of 
aeration mode and HRT on different nitrogen compounds removal and accumulation rates through the biofilm. Continuous aeration led to higher ammonia removal as well as accumulating nitrate as the endproduct. On the other hand, although intermittent aeration resulted in less ammonia removal, TN removal was identified as the dominant pathway under this aeration mode, which showed the capability of establishing a single-stage biofilm-based total nitrogen removal process. Based on the ammonia loading vs. removal rate observed in the MABR pilot, ammonia removal achieved the discharge limit ( $2.5 \mathrm{mg} / \mathrm{L})$, highlighting the possibility of operating flow-through MABR as the only treatment step without any downstream process. Another highlighted finding was a $20 \%$ increase in ammonia removal rate after the slough-off occurred in R4, most probably, due to the higher ammonia flux into the biofilm resulting from reduced diffusion resistance for ammonia molecules that can address the concerns regarding the common slough-off issue in MABR.

Taken together, the results in this study stand for the fact that the unique counter-diffusional biofilm formed in MABR facilitates one-stage biofilm-based total nitrogen removal by hiring different strategies such as aeration mode and HRT. Therefore, MABR would enable different wastewater treatment plants to fulfill the treatment targets. In plants that aim to remove only ammonia, a combination of non-scoured conditions and continuous aeration might be a proper alternative to achieve higher ammonia removal efficiency while no energy is consumed to scour the biofilm. This strategy might have a high risk of slough-off, which can be considered a benefit since it increases the removal efficiency when the main target is ammonia removal. However, for the WWTPs requiring total nitrogen removal, intermittent aeration should be considered as one of the necessary design parameters.

\section{Declarations}

Ethics approval and consent to participate: Not applicable

Consent for publication: Not applicable

Availability of data and materials: The datasets used and/or analyzed during the current study are available from the corresponding author on reasonable request.

Competing interests: The authors declare that they have no competing interests

Authors' contribution: Material preparation, data collection and analysis were performed by Sadaf Mehrabi. Study conception and experiments design were carried out by Sadaf Mehrabi, Martha Dagnew and Dwight Houweling. The first draft of the manuscript was written by Sadaf Mehrabi and Martha Dagnew commented on previous versions of the manuscript. All authors read and approved the final manuscript.

\section{Funding}

This research is funded by the Natural Sciences and Engineering Research Council of Canada and Ontario Centre of Excellence. 


\section{References}

1. Andreottola G, Foladori R, Ragazzi M, Tatano F (2000) Experimental comparison between MBBR and activated sludge system for the treatment of municipal wastewater. water Sci Technol 41:375-382

2. Castrillo M, Díez-Montero R, Esteban-García AL, Tejero I (2019) Mass transfer enhancement and improved nitrification in MABR through specific membrane configuration. Water Res 152:1-11. https://doi.org/10.1016/j.watres.2019.01.001

3. Cote P, Bersillon J-L, Huyard A (1989) Bubble-free aeration using membranes: mass transfer analysis. J Memb Sci 47:91-106

4. Côté P, Peeters J, Adams N, Hong Y, Long Z, Ireland J (2015) A New Membrane-Aerated Biofilm Reactor for Low Energy Wastewater Treatment: Pilot Results. Proc. Water Environ. Fed. 13, 42264239. https://doi.org/10.2175/193864715819540883

5. Cydzik-Kwiatkowska A, Zielińska M (2016) Bacterial communities in full-scale wastewater treatment systems. World J Microbiol Biotechnol 32:1-8. https://doi.org/10.1007/s11274-016-2012-9

6. Da Silva TS, Matsumoto T, Anjos D, Albertin ML, L.L (2018) Organic Matter Removal in a MembraneAerated Biofilm Reactor. J Environ Eng (United States) 144:1-6. https://doi.org/10.1061/(ASCE)EE.1943-7870.0001393

7. Downing LS, Bibby KJ, Esposito K, Fascianella T, Tsuchihashi R, Nerenberg R (2010) Nitrogen Removal from Wastewater Using a Hybrid Membrane-Biofilm Process: Pilot-Scale Studies. Water Environ Res 82:195-201. https://doi.org/10.2175/106143009x426103

8. Downing LS, Nerenberg R (2008) Effect of oxygen gradients on the activity and microbial community structure of a nitrifying, membrane-aerated biofilm. Biotechnol Bioeng 101:1193-1204. https://doi.org/10.1002/bit.22018

9. Germain E, Bancroft L, Dawson A, Hinrichs C, Fricker L, Pearce P (2018) Evaluation of hybrid processes for nitrification by comparing MBBR / AS and IFAS configurations. https://doi.org/10.2166/wst.2007.240

10. Gilmore KR, Terada A, Smets BF, Love NG, Garland JL (2013) Autotrophic Nitrogen Removal in a Membrane-Aerated Biofilm Reactor Under Continuous Aeration: A Demonstration. Environ Eng Sci 30:38-45. https://doi.org/10.1089/ees.2012.0222

11. Gong W, Fan A, Zhang H, Luo L, Liang H (2020) Cow manure anaerobic fermentation effluent treatment by oxygen-based membrane aerated biofilm reactor. Chem Eng J 395:125116. https://doi.org/10.1016/j.cej.2020.125116

12. Gong Z, Yang F, Liu S, Bao H, Hu S, Furukawa K (2007) Feasibility of a membrane-aerated biofilm reactor to achieve single-stage autotrophic nitrogen removal based on Anammox. Chemosphere 69:776-784. https://doi.org/10.1016/j.chemosphere.2007.05.023

13. Gu Y, Li T, Li H (2018) Biofilm formation monitored by confocal laser scanning microscopy during startup of MBBR operated under different intermittent aeration modes. Process Biochem 74:132140. https://doi.org/10.1016/j.procbio.2018.08.032 
14. Hewawasam C, Matsuura N, Maharjan N, Hatamoto M (2017) Oxygen transfer dynamics and nitrification in a novel rotational sponge reactor. Biochem Eng J 128:162-167. https://doi.org/10.1016/j.bej.2017.09.021

15. Houweling D, Peeters J, Cote P, Long Z, Adams N (2017a) Proving Membrane Aerated Biofilm Reactor (MABR) Performance and Reliability: Results from Four Pilots and a Full-Scale Plant, in: Proceedings of the Water Environment Federation. pp. 272-284. https://doi.org/10.2175/193864717822155786

16. Houweling D, Peeters J, Cote P, Long Z, Nick A (2017b) Proving Membrane Aerated Biofilm Reactor (MABR) Performance and Reliability: Results from Four Pilots and a Full-Scale Plant Proving Membrane Aerated Biofilm Reactor (MABR ) Performance and Reliability : Results from Four Pilots and a Full-Scale Plant, in: Proceedings of the Water Environment Federation. pp. 272-284. https://doi.org/10.2175/193864717822155786

17. lannacone F, Di F, Granata F, Gargano R, Pirozzi F, Esposito G (2019) Effect of carbon-to-nitrogen ratio on simultaneous nitrification denitrification and phosphorus removal in a microaerobic moving bed biofilm reactor. J Environ Manage 250:109518. https://doi.org/10.1016/j.jenvman.2019.109518

18. Ito T, Aoi T, Miyazato N, Hatamoto M, Fuchigami S (2019) Diversity and abundance of denitrifying bacteria in a simultaneously nitrifying and denitrifying rotating biological contactor treating real wastewater at low temperatures 2, 58-70. https://doi.org/10.2166/h2oj.2019.021

19. Kunlasubpreedee P, Visvanathan C (2020) Performance Evaluation of Membrane-Aerated Biofilm Reactor for Acetonitrile Wastewater Treatment. J Environ Eng (United States) 146:1-7. https://doi.org/10.1061/(ASCE)EE.1943-7870.0001706

20. Lan M, Li M, Liu J, Quan X, Li Y, Li B (2018) Coal chemical reverse osmosis concentrate treatment by membrane-aerated biofilm reactor system. Bioresour Technol 270:120-128. https://doi.org/10.1016/j.biortech.2018.09.011

21. Li Y, Zhang K (2018) Pilot scale treatment of polluted surface waters using membrane-aerated biofilm reactor (MABR). Biotechnol Biotechnol Equip 32:376-386. https://doi.org/10.1080/13102818.2017.1399826

22. Liao JJ (2017) Experimental pilot scalecomparison between integrated fixed film activated sludge (IFAS) and traditional activated sludge (AS) system for municipal wastewater treatment. Lamar University

23. Lin J, Zhang P, Li G, Yin J, Li J, Zhao X (2016) Effect of COD / N ratio on nitrogen removal in a membrane-aerated bio film reactor. Int Biodeterior Biodegradation 113:74-79. https://doi.org/10.1016/j.ibiod.2016.01.009

24. Lin J, Zhang P, Yin J, Zhao X, Li J (2015) Nitrogen removal performances of a polyvinylidene fluoride membrane-aerated biofilm reactor. Int Biodeterior Biodegrad 102:49-55. https://doi.org/10.1016/j.ibiod.2015.01.013

25. Liu R, Wang Q, Li M, Liu J, Zhang W, Lan M, Du C, Sun Z, Zhao D, Li B (2020) Advanced treatment of coal chemical reverse osmosis concentrate with three-stage MABR. RSC Adv 10:10178-10187. https://doi.org/10.1039/c9ra10574c 
26. Ma Y, Domingo-fe C, Gy B, Smets BF (2017) Intermittent Aeration Suppresses Nitrite-Oxidizing Bacteria in Membrane-Aerated Bio fi Ims: A Model-Based Explanation. https://doi.org/10.1021/acs.est.7b00463

27. Martin KJ, Boltz JP, Nerenberg R (2012) The Membrane Biofilm Reactor (MBfR) for Wastewater Treatment: Applications, Design Considerations, and Technology Outlook. Proc. Water Environ. Fed. 2012, 4032-4044. https://doi.org/10.2175/193864712811708347

28. Mehrabi S, Houweling D, Dagnew M (2020) Establishing Mainstream Nitrite Shunt Process in Membrane Aerated Biofilm Reactors: Impact of Organic carbon and biofilm scouring intensity. J. water Process Eng. In press

29. Mei X, Liu J, Guo Z, Li P, Bi S, Wang, Yong, Yang Y, Shen W, Wang, Yihan, Xiao Y, Yang X, Zhou B, Liu $\mathrm{H}$, Wu S (2019) Simultaneous p-nitrophenol and nitrogen removal in PNP wastewater treatment: Comparison of two integrated membrane-aerated bioreactor systems. J Hazard Mater 363:99-108. https://doi.org/10.1016/j.jhazmat.2018.09.072

30. Mota C, Head MA, Ridenoure JA, Cheng JJ, lii FLDLR (2005) Effects of Aeration Cycles on Nitrifying Bacterial Populations and Nitrogen Removal in Intermittently Aerated Reactors. Appl Environ Microbiol 71:8565-8572. https://doi.org/10.1128/AEM.71.12.8565

31. Onnis-Hayden A, Dair D, Johnson C, Schramm A, Gu AZ (2007) Kinetics and nitrifying populations in nitrogen removal processes at full-scale integrated fixed-film activated sludge (IFAS) plant, in: WEFTEC. pp. 3099-3119

32. Pankhania M, Brindle K, Stephenson T (1999) Membrane aeration bioreactors for wastewater treatment: Completely mixed and plug-flow operation. Chem Eng J 73:131-136. https://doi.org/10.1016/S1385-8947(99)00026-1

33. Peeters J, Long Z, Houweling D, Cote P, Daigger GT, Snowling S (2017) Nutrient Removal Intensification with MABR - Developing a Process Model Supported by Piloting. https://doi.org/10.2175/193864717821494204

34. Pellicer-Nàcher C, Domingo-Félez C, Lackner S, Smets BF (2013) Microbial activity catalyzes oxygen transfer in membrane-aerated nitritating biofilm reactors. J Memb Sci 446:465-471. https://doi.org/10.1016/j.memsci.2013.06.063

35. Pellicer-Nàcher C, Sun S, Lackner S, Terada A, Schreiber F, Zhou Q, Smets BF (2010) Sequential aeration of membrane-aerated biofilm reactors for high-rate autotrophic nitrogen removal: Experimental demonstration. Environ Sci Technol 44:7628-7634. https://doi.org/10.1021/es1013467

36. Potvin CM, Long Z, Zhou H (2012) Removal of tetrabromobisphenol A by conventional activated sludge, submerged membrane and membrane aerated biofilm reactors. Chemosphere 89:11831188. https://doi.org/10.1016/j.chemosphere.2012.07.011

37. Premarathna NHSM, Visvanathan C (2019) Enhancement of organic matter and total nitrogen removal in a membrane aerated biofilm reactor using PVA-Gel bio-carriers. Bioresour Technol Reports 8:100325. https://doi.org/10.1016/j.biteb.2019.100325 
38. Quan X, Huang K, Li M, Lan M, Li B (2018) Nitrogen removal performance of municipal reverse osmosis concentrate with low $\mathrm{C} / \mathrm{N}$ ratio by membrane-aerated biofilm reactor. Front Environ Sci Eng 12. https://doi.org/10.1007/s11783-018-1047-6

39. Regmi P, Thomas W, Schafran G, Bott C, Rutherford B, Waltrip D (2011) Nitrogen removal assessment through nitrification rates and media biofilm accumulation in an IFAS process demonstration study. Water Res 45:6699-6708. https://doi.org/10.1016/j.watres.2011.10.009

40. Rice EW, Baird RB, Eaton AD, Clesceri L (2012) Standard methods for the examination of water and wastewater. Washington, USA

41. Semmens M (2005) Membrane technology: pilot studies of membrane-aerated bioreactors

42. Shanahan JW, Semmens MJ (2006) Influence of a nitrifying biofilm on local oxygen fluxes across a micro-porous flat sheet membrane. J Memb Sci 277:65-74.

https://doi.org/10.1016/j.memsci.2005.10.010

43. Stamatopoulou P (2019) Partial Nitritation Anammox Process for Sidestream Wastewater Treatment in MABR Technology

44. Sun L, Wang Z, Wei X, Li P, Zhang H, Li M, Li B, Wang S (2015) Enhanced biological nitrogen and phosphorus removal using sequencing batch membrane-aerated biofilm reactor. Chem Eng Sci 135:559-565. https://doi.org/10.1016/j.ces.2015.07.033

45. Tchobanoglous G, Stensel HD, Tsuchihashi R, Burton F, Abu-Orf M, Bowden G, Pfrang W (2014) Wastewater engineering: treatment and resource recovery, 5th edn. McGraw-Hill Education

46. Tian H, Yanzhuo Hu, Xu X, Hui M, Hu, Yuansen, Qi W, Xu H, Li B (2019) Enhanced wastewater treatment with high o-aminophenol concentration by two-stage MABR and its biodegradation mechanism. Bioresour Technol 289:121649. https://doi.org/10.1016/j.biortech.2019.121649

47. Wei X, Li B, Zhao S, Qiang C, Zhang H, Wang S (2012) COD and nitrogen removal in facilitated transfer membrane-aerated biofilm reactor (FT-MABR). J Memb Sci 389:257-264. https://doi.org/10.1016/j.memsci.2011.10.038

48. Wu Y, Wu Z, Chu H, Li J, Ngo HH, Guo W, Zhang N, Zhang H (2019) Comparison study on the performance of two different gas-permeable membranes used in a membrane-aerated biofilm reactor. Sci Total Environ 658:1219-1227. https://doi.org/10.1016/j.scitotenv.2018.12.121

49. Yang S, Yang F (2011) Nitrogen removal via short-cut simultaneous nitrification and denitrification in an intermittently aerated moving bed membrane bioreactor. J Hazard Mater 195:318-323. https://doi.org/10.1016/j.jhazmat.2011.08.045

\section{Figures}


(a)

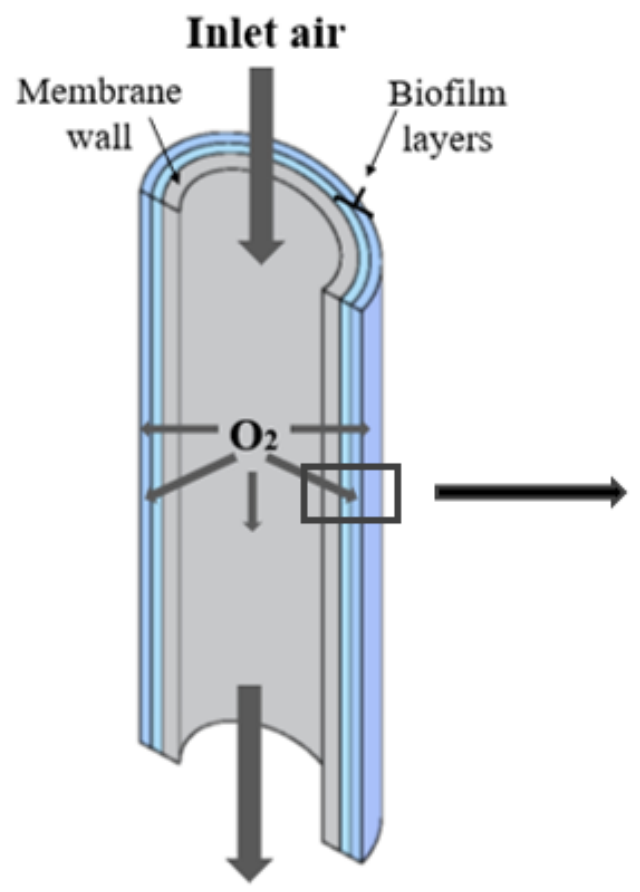

Exhaust air

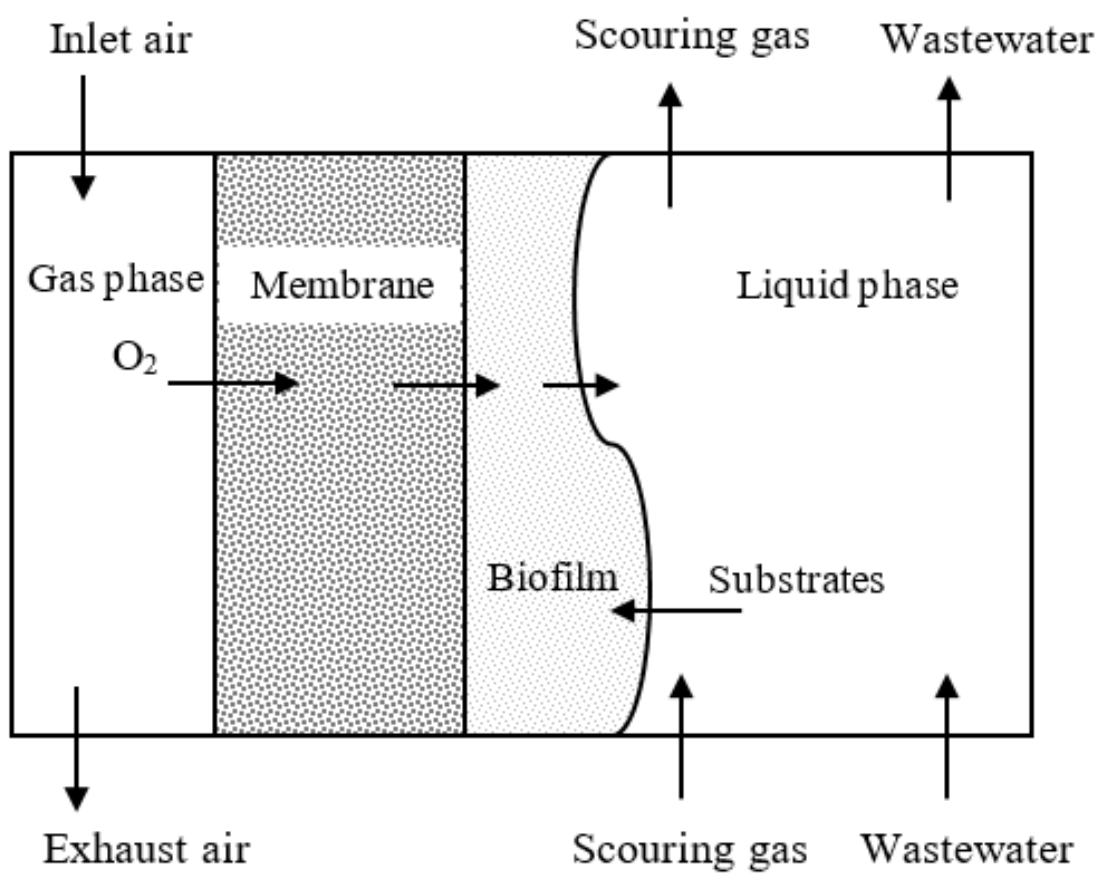

\section{Figure 1}

a) Schematic of a cross-sectional view of the membrane fiber, b) mass transfer within membrane and biofilm 


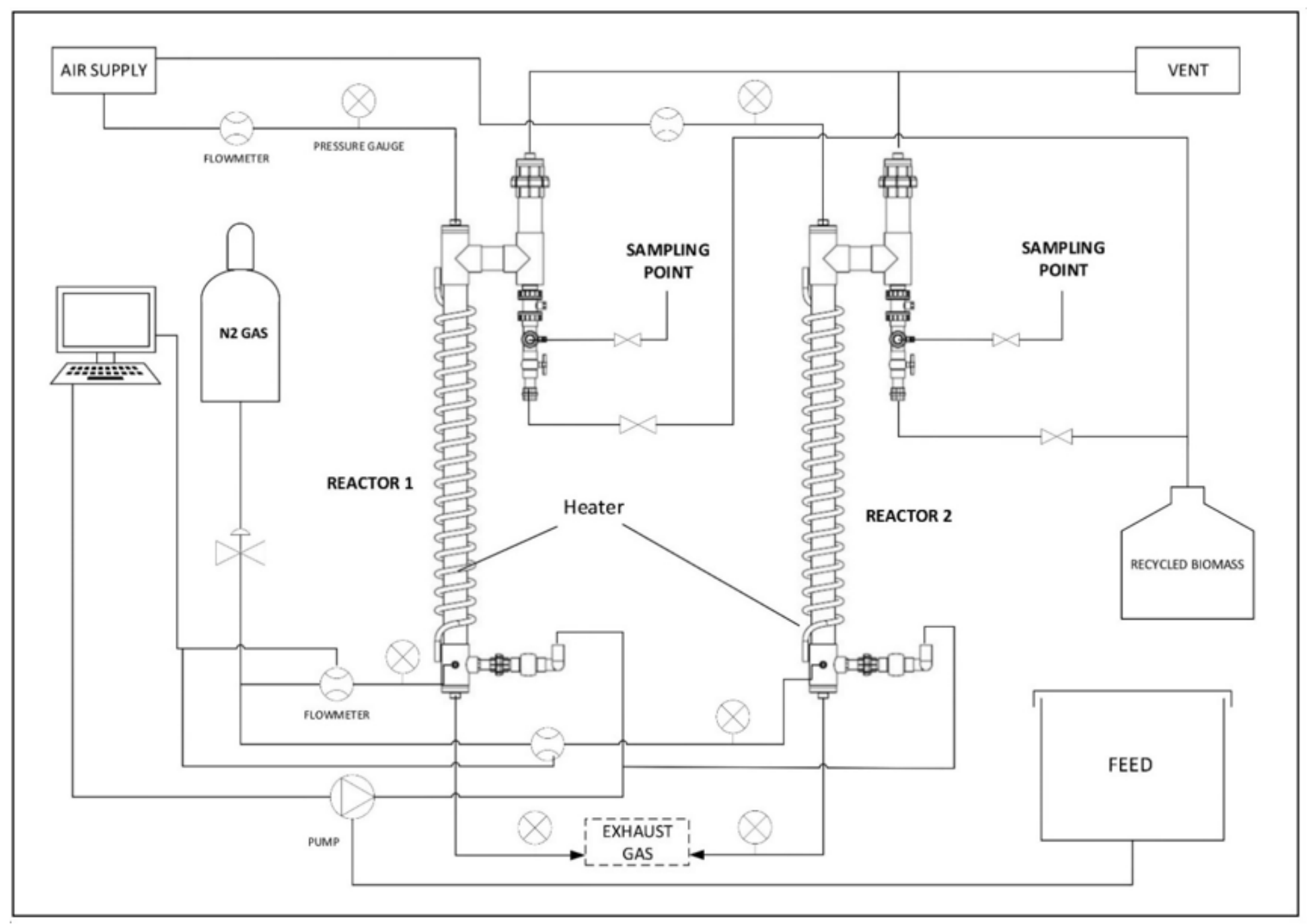

Figure 2

MABR pilot layout (Stamatopoulou, 2019) 
(a)
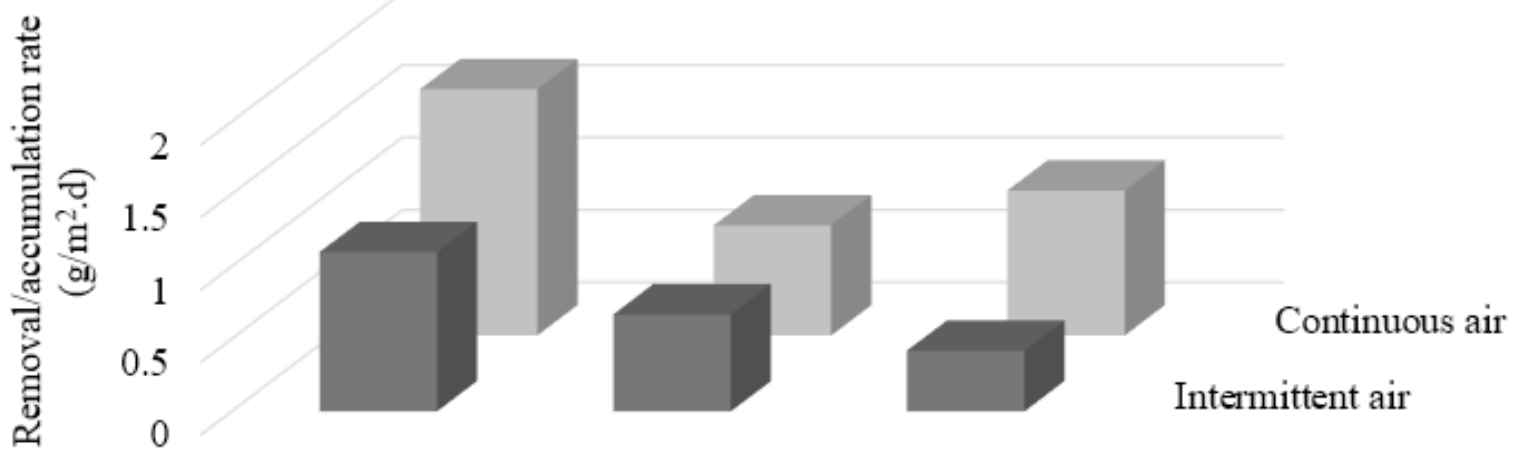

NH4 removal TN removal rate Remained NO3 rate

$$
\text { - Intermittent air } \quad \text { Continuous air }
$$

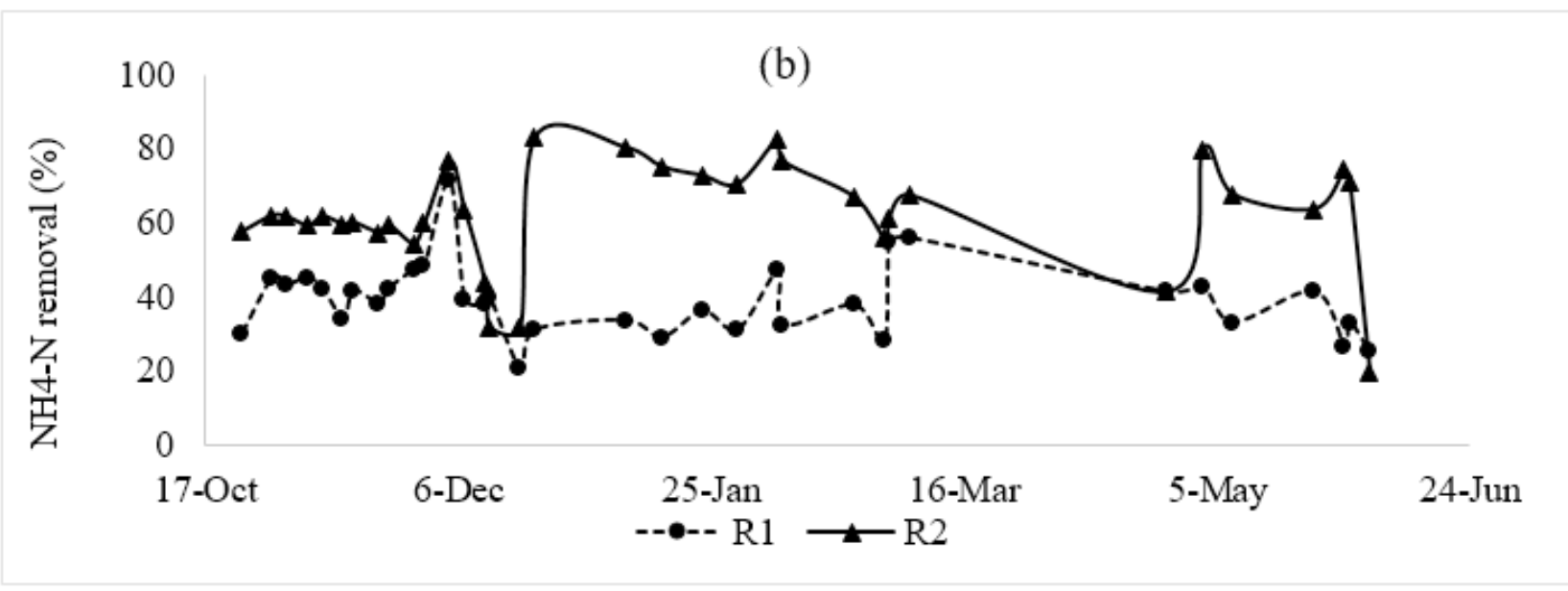

(c)

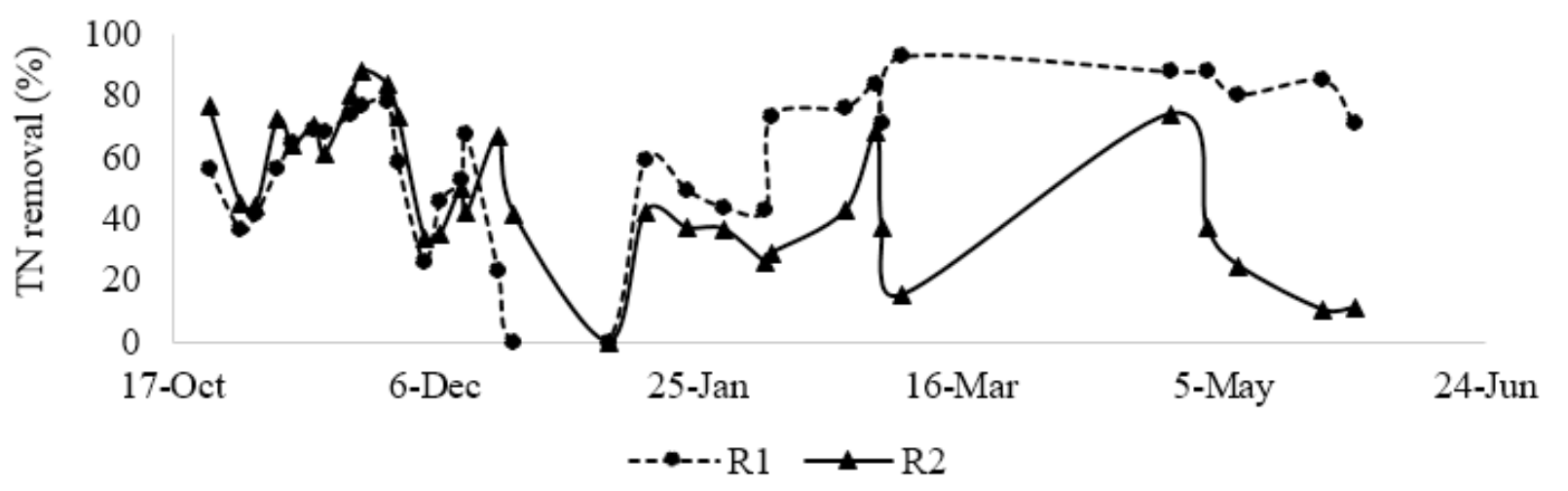

\section{Figure 3}

a) Nitrogen compounds removal/accumulation rates in intermittent (R1) and continuous (R2) aeration modes, b) Ammonia removal percentage, c) Total nitrogen removal percentage in R1 and R2 
(a)

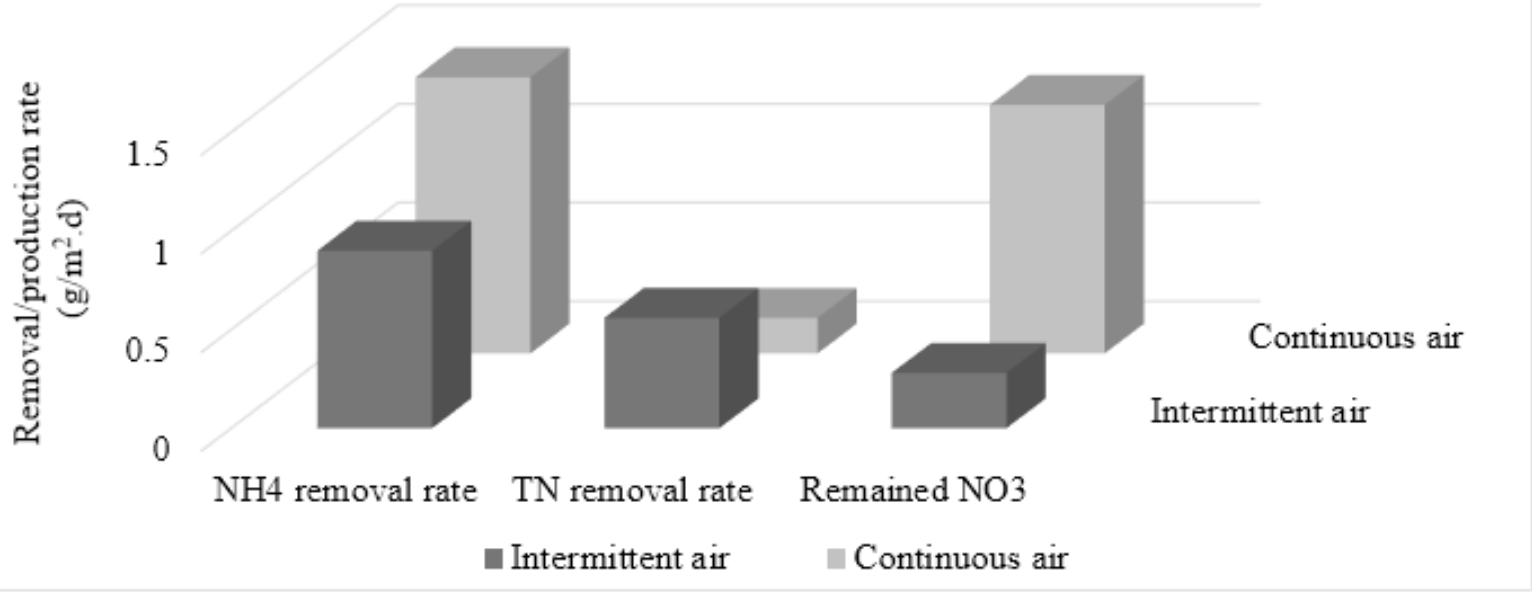

(b)

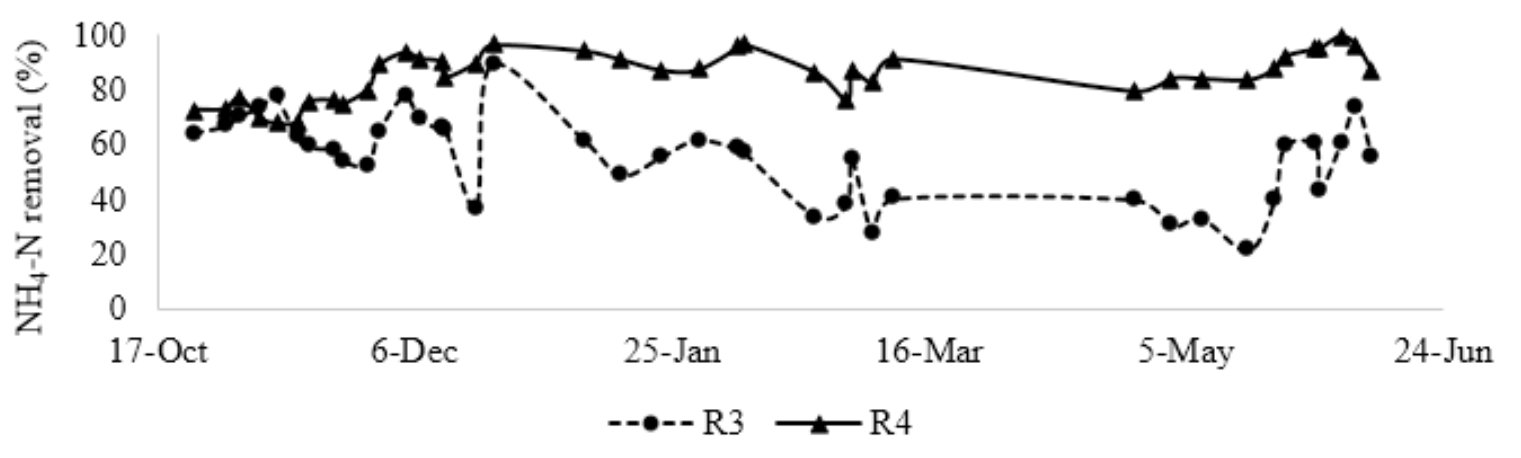

(c)

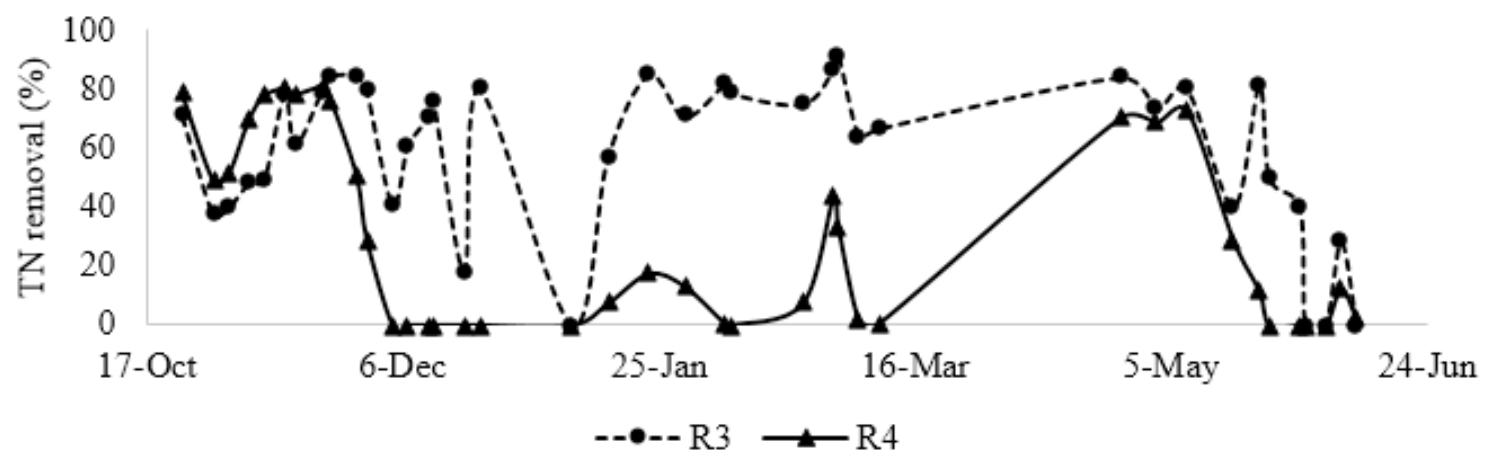

Figure 4

a) Nitrogen compounds removal/accumulation rates in intermittent (R3) and continuous (R4) aeration modes, b) Ammonia removal percentage, c) Total nitrogen removal percentage in R3 and R4 


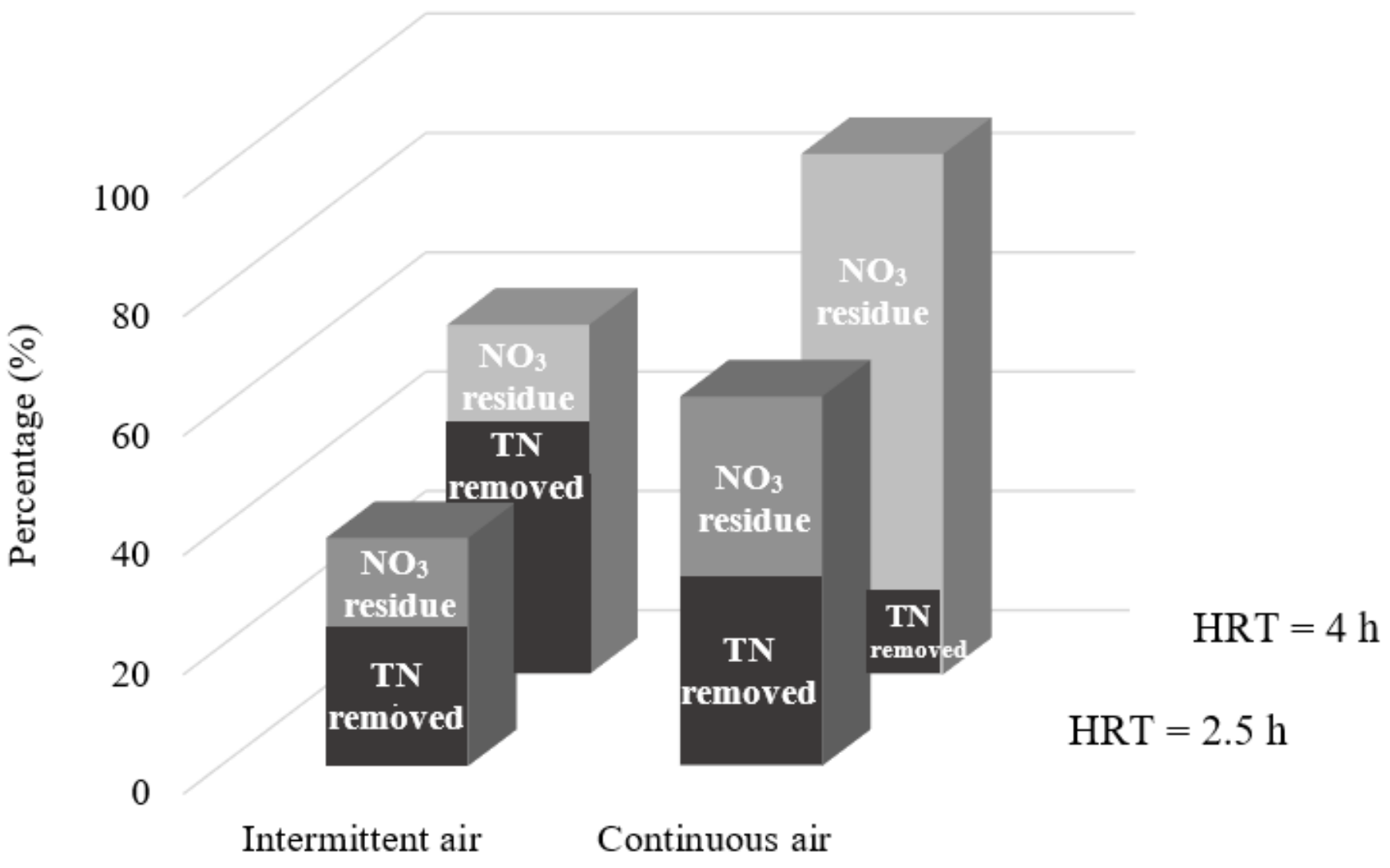

Figure 5

The fate of removed ammonia in MABRs operated under varying aeration modes and HRTs 

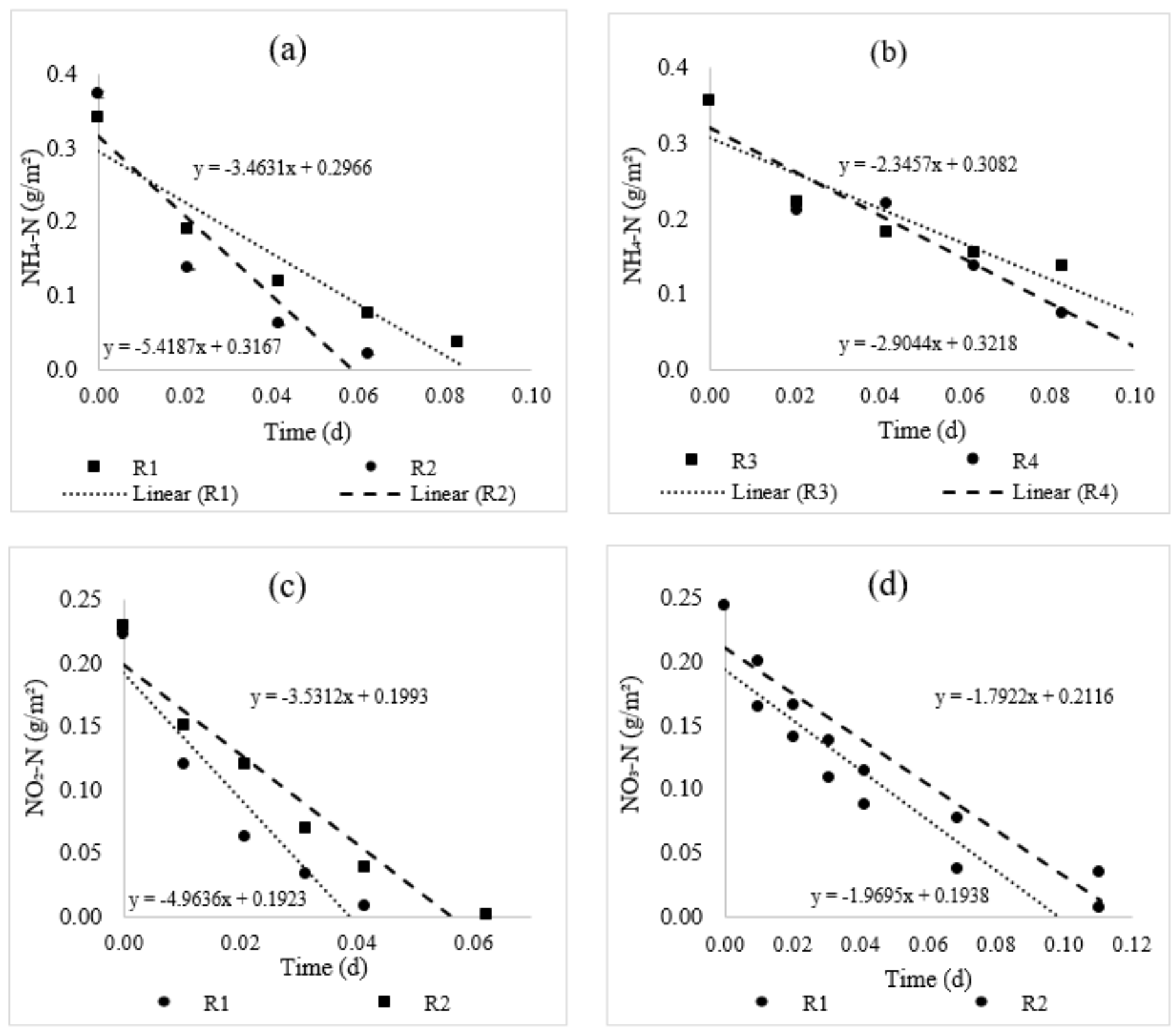

Figure 6

Batch tests: a) Ammonia removal rate in R1 and R2, b) Ammonia removal rate in R3 and R4, c) Nitrite removal rate in R1 and R2, d) Nitrate removal rate in R1 and R2 


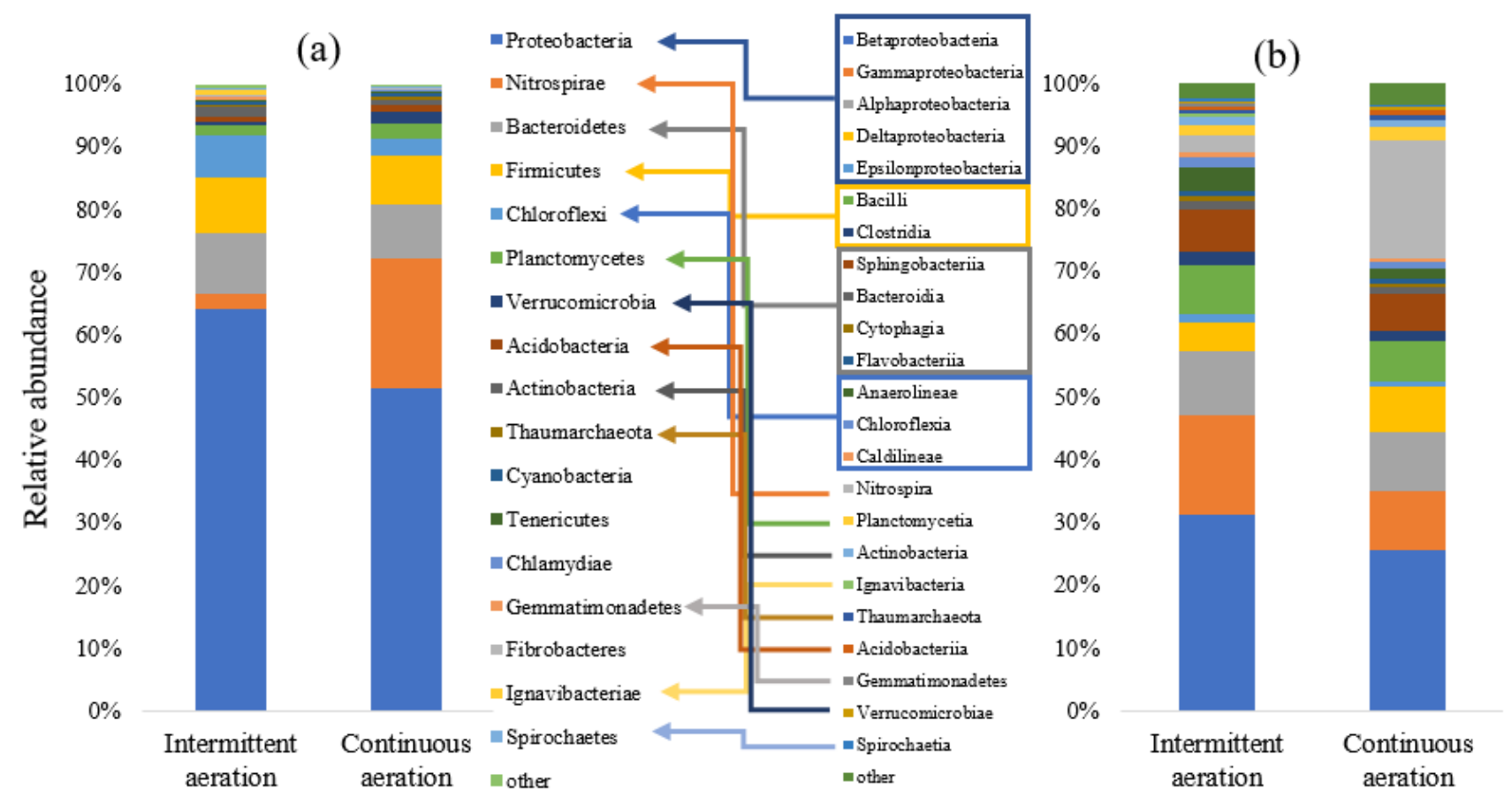

(c)
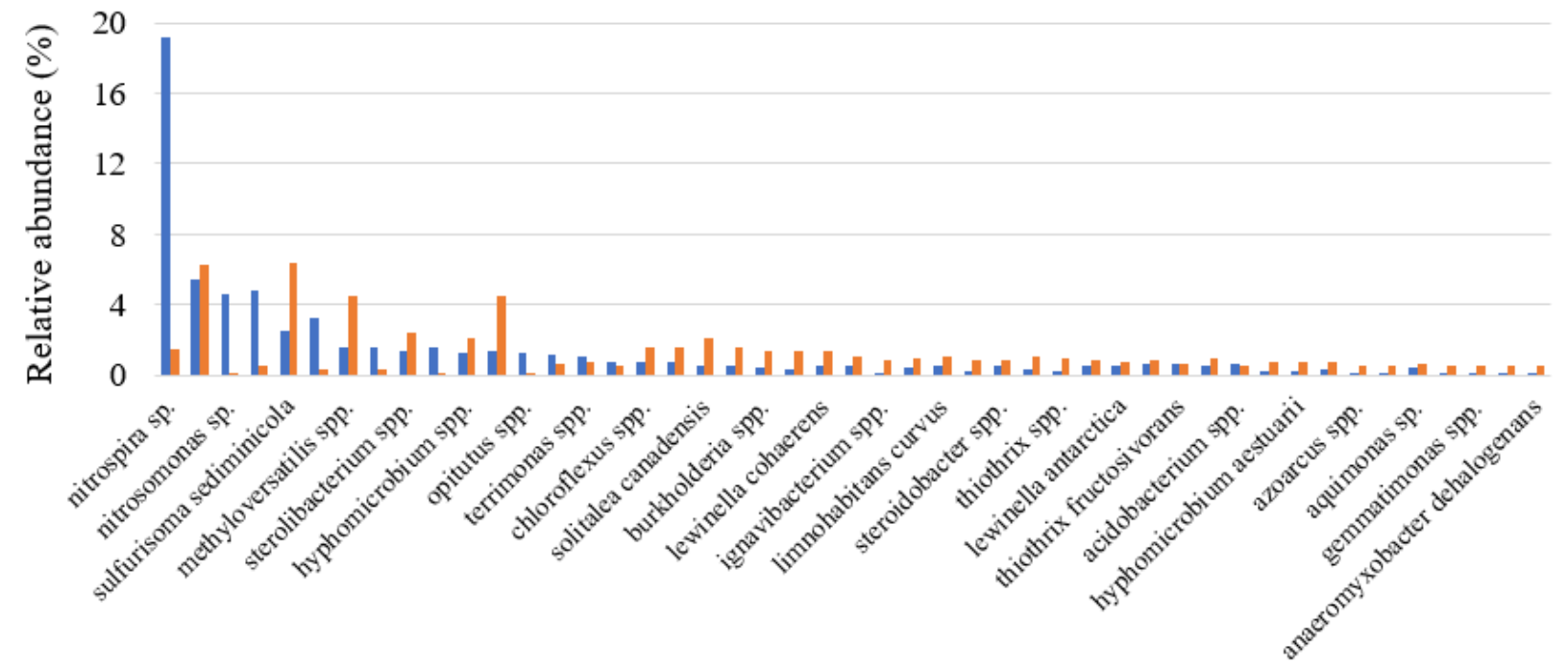

- Continuously-aerated MABR Intermittently-aerated MABR

\section{Figure 7}

Function microbial population a) phylum, b) class, and c) species level relative abundance in intermittently-aerated and continuously-aerated MABRs 

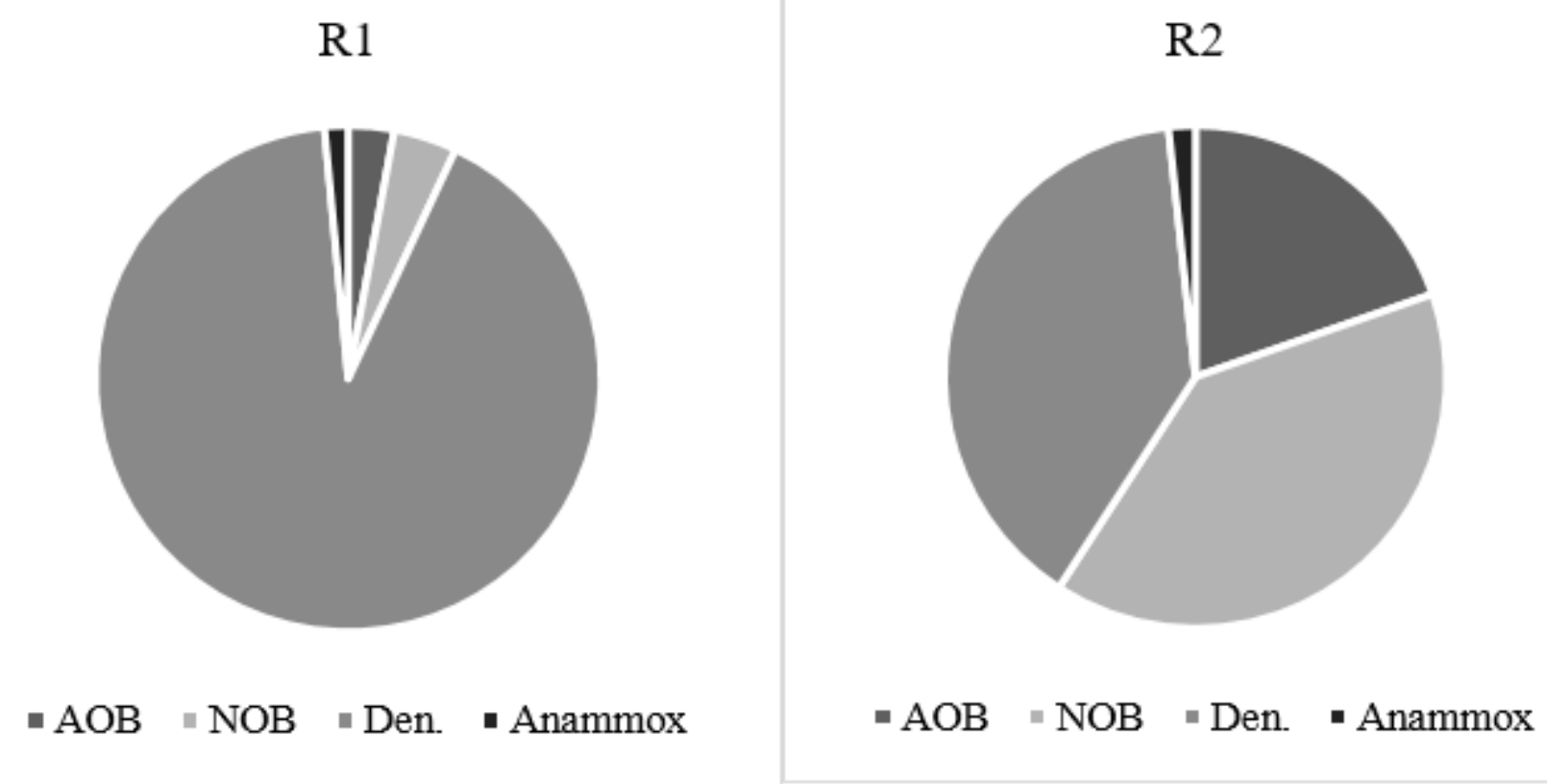

\section{Figure 8}

The relative abundance of the different microbial population in R1 and R2

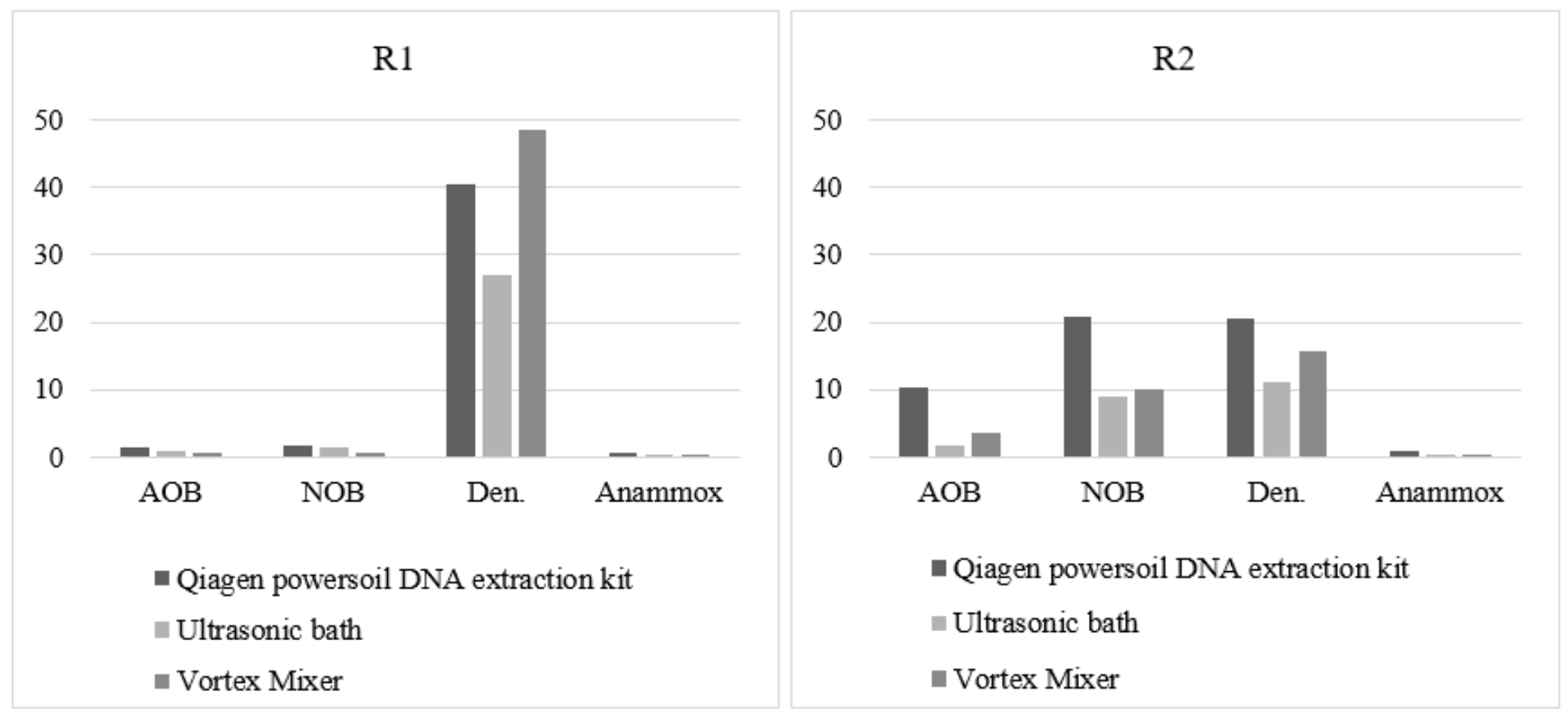

\section{Figure 9}

The relative abundance of the functional microbial population using different biofilm extraction methods in $\mathrm{R} 1$ and $\mathrm{R} 2$ 